\title{
Beating the Drum of Third World War and the First Thermonuclear War: Religion, Democracy and Nuclear Weapon Acquisition as Gadflies
}

\author{
Fa Olasupo \\ Department of Local Government Studies, Faculty of Administration, Obafemi Awolowo University, Ile-Ife, \\ Nigeria \\ Email: faolasupo@yahoo.com
}

Received 23 November 2014; accepted 8 January 2015; published 20 January 2015

Copyright (C) 2015 by author and Scientific Research Publishing Inc.

This work is licensed under the Creative Commons Attribution International License (CC BY).

http://creativecommons.org/licenses/by/4.0/

(c) (i) Open Access

\begin{abstract}
Recently, two powerful personalities have raised issues of global concern, both of which point to the fact that the world is tacitly at WW III. For Pope Francis, conflicts around the globe today are effectively "piecemeal" World War III. For the heir to the British throne, Prince Charles, President Vladimir Putin is "doing just about the same as Hitler". What informed these outbursts from these world leaders: Spiritual and the temporal? This paper is out to examine what informed these spiritual and royal outbursts.
\end{abstract}

Keywords

War, WW III, Thermonuclear, Weapon, Religion and Democracy

\section{Introduction}

The conflicts around the globe which informed Pope's prediction of imminent Third World War, already being fought at "piecemeal" level, are those of Ukraine, Iraq, Syria, Gaza and Africa (Rellandini, 2014: Online). For Africa, apart from religious cum political conflicts in Nigeria, Mali and Sudan that finally broke into two, there is also epidemic conflict that led some African and European countries to shut their air, sea and land borders against travellers from Ebola ravaged countries: Guinea, Liberia and Sierra Leone. Western world countries also have their internal conflicts that are also threatening world peace.

While, in the opinion of the Pope, "Greed, intolerance" and "the lust for power" are the motives underlying 
the decision to go to war that are "too often justified by an ideology", political scientists, on the other hand, feel that the cause of the current "piecemeal" WW III can be located in the trinity of Religion, Democracy and the desires of some second and third world countries to acquire nuclear bomb. It is the intention of this paper to demonstrate how any of these issues-Religion, Democracy and Nuclear power acquisition, rather than "Greed, intolerance and lust for power", which an analyst said the Pope had couched in the language of Christian sermon, are almost causing full-scale Third World War. Precisely, this paper intends to demonstrate how conflicts in Religion, Democracy and the rabid desire of some countries to acquire nuclear weapon can detonate nuclear bomb and thus set off what some analysts referred to as thermonuclear war (Ehret-Kump \& Spannaus, 2014).

\section{Religion}

One of the potent issues likely to ignite Third World War (WW III) is religion and has in fact started it "piecemeal" as Pope Francis puts it. Specifically, there are no less than ten (10) most important world religions but of these, two-Islam and Christianity - are the most pervasive and globally recognized. On nations' bases, adherent or votaries of these two religions have had intra and inter crisis. In Africa, spotlights of these are found mainly in Nigeria and Senegal; in the Middle East between the Palestinian and Jewish people; in Asia, China, Pakistan, and occasionally India. There is also the case of restless Dagestan Muslim population against the rest of Russian federation. In the West, especially Britain and the United States are the rumblings of Muslims against the States. Recall the issue of Michael Adebolaji and Michael Adebowale against Lee James Rigby. In the case of USA are the cases of Boston Marathon Bombers-Dzhokhar and Tamerlan Tsarnaev-who imported Islamic fundamentalism from Chechen area of Russia to USA. Added to this is Alton Alexander Nolen case. Canada has just produced its own Muslim convert in Michael Joseph Hall who converted from Christianity to Islam and took the name Michael Zehaf-Bibeau. Like in the case of Lee James Rigby, another "radicalized" Muslim attacker in Canada had earlier killed a soldier with his car (CNN, 2014a). What is common to these characters? One, all of them are Muslim converts from Christianity; two, all of them engaged in gruesome murder of their victims through beheading similar to how, Islamic State in Iraq and Syria (ISIS) or Islamic State in Iraq and the Levant (ISL) are beheading Americans, Britons and French citizens in Iraq, Syria and Algeria. Interestingly, Boko Haram insurgent in Nigeria is also said to have beheaded a pilot. Last but not the least is the Western converts, particularly Americans and Britons, to Arabs and ISIS fighters in Arab lands.

To date, the numbers of beheaded Westerners by ISIS included American reporter James Foley, AmericanIsraeli Journalist Steven Sotloff, and Abdul-Raham or Mr. Peter Kassig; British aid worker David Haines (News, 2014); French Herve Gourdel was beheaded not in ISIS stronghold but by ISL sympathizers in Algeria (Johnston \& Willsher, 2014); last but not the least is the showing of video clip by Boko Haram "that shows the charred wreckage of a plane and the beheading of a man it identified as its pilot" (This Day, 2014). I do not know whether this new global culture of beheading started in the West or the Middle East. But it is on record that Muslim converts: Michael Adebolaji and Michael Adebowale started it in London on 22 May 2013 using "Car, cleaver, knife and revolver" (Wikipedia, 2014a); for the Boko Haram, the instrument of beheading was axe, while the ISIS, as regularly shown by CNN, and Alton Alexander, relied mainly on knife.

Regardless of which country exported this savage culture of murder to the other, these show civilization is under siege. These savage ways of killing are, islamically, reserved for killing of rams and all other edible mammals and birds. As a matter of fact, Quran frowns on any mammal or bird killed for eating without passing through this process of death - slaughtering. It does not even encompasses beheading, it gets to that stage of beheading when the entire body of the animal or bird concerned is being pieced for consumption. So, slaughtering and beheading are not meant for Human Beings.

Stoning, another gruesome way of murdering, is another issue the West seriously frowns against but which Islam or Quran recommended for adultery. This may also need modernization but how could it be done in a way that it would not offend Quran? It cannot be erased from the Holy Quran without tampering with the words of God! In any case, stoning of adulterer to death is not limited to the Holy Quran, it is also found in the Law of Moses that commanded the Jews to "stone such women" (Bible, 2008: p. 997). But the Jews had begun to modernize this even before the advent of modern system of government. How? The accused woman was brought to Jesus for judgment that with a simple question disarmed and dispersed her accusers - the Pharisees. "If any one of you is without sin, let him be the first to throw a stone", Jesus asked them. When the accusers had all disappeared, Jesus asked again, "woman, where are they", "has no-one condemned you", "no-one sir", the accused woman said. "Then neither do I condemn you", Jesus declared. "Go now and leave your life of sin" (Bible, 2008: 
p. 997). This is clearly Biblical modernization of stoning, as punishment for adultery by a Jew (Jesus) against fellow Jews (Pharisees) and, the Law of Moses. The modernization under Western civilization on the other hand is demarcation of spirituality from secularity especially in all countries Western civilization impacted upon. If western technologies: means of transportation, communications, medicine and weapons of war are found appealing, adopted and employed by Islamic world then some of their (Western) values, criticism in particular, must be looked into.

Apart from stoning to death, there is also Islamic way of dressing which Western world find repugnant especially purdah or complete veil, particularly by women. Called differently in other parts of the world, purdah is a global way of dressing. In most African cultures there are masquerade festivals which Nobel Laureate Professor Wole Soyinka comes to celebrate occasionally at my University, Obafemi Awolowo University. Sometime ago, Professor Wole Syinka alluded to the fact that Christendom has its own purdah or masquerade-Father Christmas. So, there is no religion that does not have its own form of purdah or the other. While Islamic "purdah" is a daily affair, "purdah" of other parts of the world is seasonal. What the west however complains about is making this a complete way of life as in the case of Islamic world, to the extent of dressing like this to the offices, airports and other public places where identity of who is inside the purdah need identification. But at least, there are few towns in the Western world where Father Christmas is a way of life. In such towns it is easier to observe light poles painted like "candy canes, listening to Christmas music that played in shops even during summer" in these Christmas-named and themed towns - Lapland, Indiana, Finland, Alaska and Christmas island in Australia-Santa Claus (Father Christmas) receive hundreds of thousands of letters year-round (Snedden, 2014). In Figure 1 is the image of perpetual father Christmas in some towns in the Western world.

In the past, this way of dressing (purdah) generated a lot of controversy between Muslim community and the authorities of my University. This was because some ghost students hide under this to come and sit for an exam for either their girl or boy friends; a situation that led the University to articulate a code of dressing. "Female students could henceforth put on hijab or the veil but with the proviso that they should be ready to unveil when authorities wish to know their true identities, particularly during examinations when the problem of ghost students sitting for examination for their friends is rampart" (Olasupo, 2011: p. 115-116). However, the identifier of the person inside the purdah or veil must be a female rather than male lecturer. Of recent is also the case of several suspected "al-Qaeda militants disguised fully as veiled women" attempting border crossing in Hawdh area of Yemen. They are often on mission to attack Saudi border guards; they were instantly shot dead (News sections, 2014a). Women in conservative Yemen often pass through checkpoints without being searched and the militants saw this as a loophole they could exploit. See Figure 2 for the picture of male militants in "purdah" attempting border crossing.

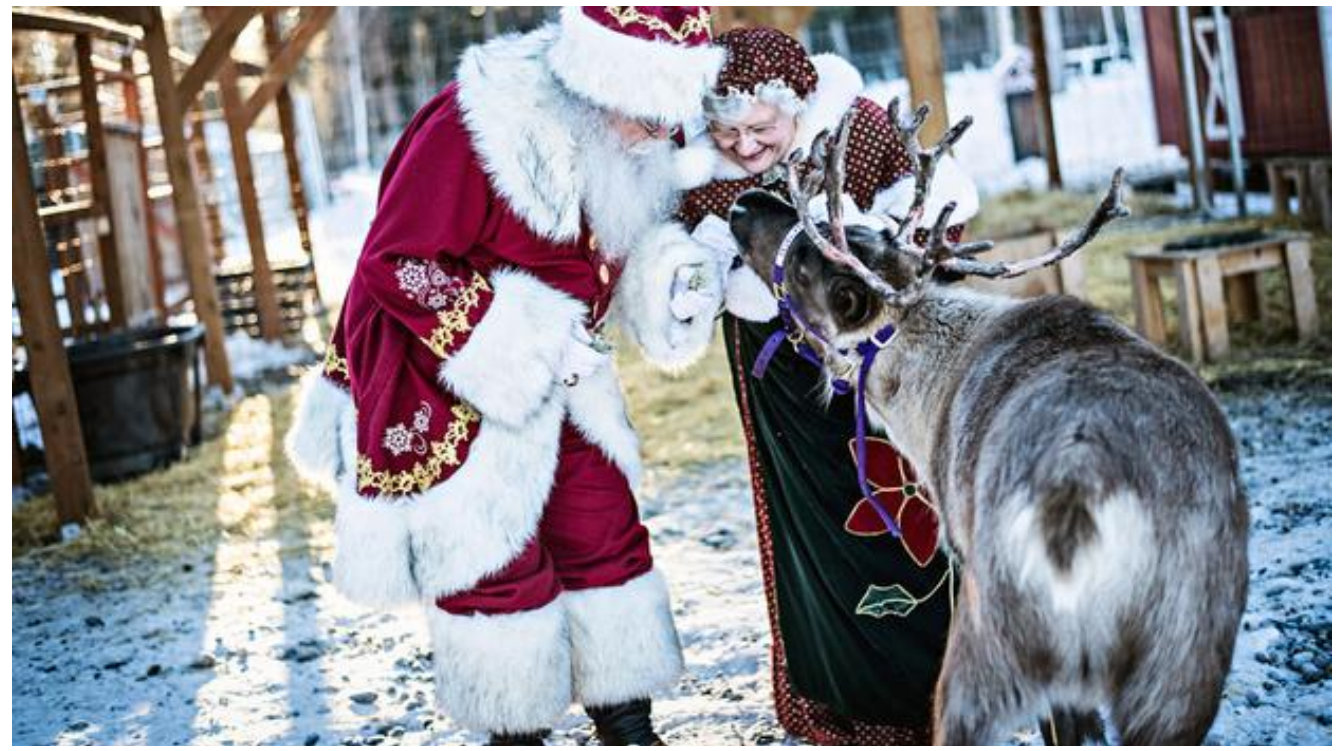

Figure 1. Living where it is perpetually Christmas poses unique challenges (Santa Claus House). This is Father Christmas in Christian form of "purdah". Source (Snedden, 2014). 


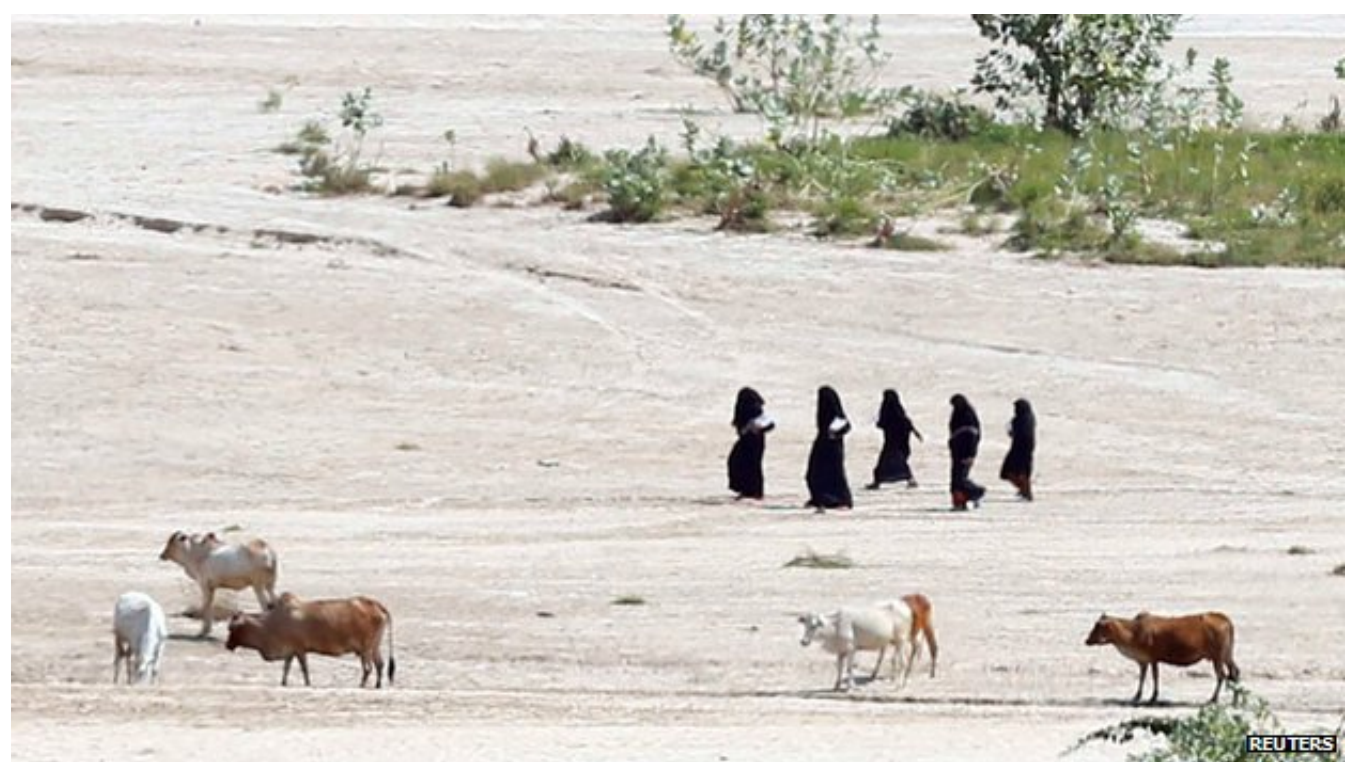

Figure 2. Women in conservative Yemen often pass through checkpoints without being searched. Seizing this opportunity, "several suspected al-Qaeda militants, disguised as fully veiled women, have reportedly been shot dead by Yemeni security forces near the Saudi border" (News Sections, 2014a).

The deceit by militants appearing in purdah to achieve their Jihadist goal is not limited to al-Qaeda militants alone, it has reared its head in London where "A gay Muslim man from West London dressed up and performs as a woman in a nightclub" (McDermott, 2015). "AsifQuarishi from Southhall runs an Asian gay night and says he wants to change attitudes by challenging traditional values". According to him, "I'm inspiring people to be themselves", he said, "I $m$ just being me". He however raises alarm recently claiming "he faces regular death threats from fundamentalists (McDermott, 2015). See him in Figure 3.

There are three distinct ways of female dressings in the Islamic world: Purdah, Veil and hijab or head scarf. Finding a mean of these types of Muslim way of dressing was thus the concern of Western powers. To this extent, Western acceptable Muslim way of dressing has been severally demonstrated by not only the former Secretary of State, Hillary Clinton, but also by Christiana Amanpour and Hala Gorani, the global megaphones of unipolar world. On many occasions when the former Secretary of State was on trips to Arab lands, she showed cased acceptable Muslim way of dressing to the unipolar world; and so are Christiana Amanpour and Hala Gorani. The choice of Ijab by the West is not based on modernization and westernization alone but more importantly because it has Christian underpinning. For instance, in the 1st Corinthian, Paul, an authority on life in the earlier Christian communities, said "women should have their heads covered when they prophesy" (Timpson, 2014). On ways of religious dressing by women, this is another convergence of Islam and Christianity. Presumed to be the next and the first female President of United States, Hillary Clinton is most likely to be the one to finally unite western values with those of the Arab world; as she behaves like St Paul: "To the Jews I became like a Jew, to win the Jews... To those not having the [Jewish] law I became like one not having the law... I have become all things to all people so that by all possible means I might save some" (Timpson, 2014). Acceptable way of Muslim women dressing to the West is below demonstrated by Hillary Clinton in Figure 4.

Among all the world religions, Islam and Christianity are the most important, pervasive and conflicting, globally. Elements within Islamic religion that are depicted as terrorists are ISIS, Al Qaeda, Boko Haram and Al Shabab, which entire world is now responding to through global coalition (Olasupo, 2013: p. 29; 2014: p. 317). See Table 1.

Critical questions which Western powers and their allies need to focus on and provide genuine answers to are why are all designated terrorists Muslim? Why are some of their (western) citizens converting to Islam and Arab to the extent that they travel all the way from western nations to ISIS strongholds to join them in the Jihad fight? For instance, an estimated 500 Britons have travelled abroad to become Jihadist, and about half have returned. In fact as many as five more people from UK join ISIS or Islamic state organizations every week. Generally, in Europe, especially in areas which are geographically close to the fight, hundreds more came from there. USA, the 


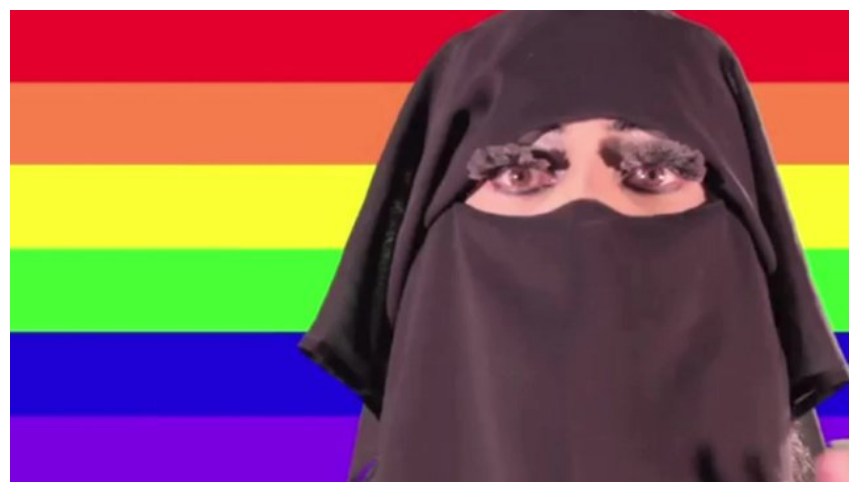

Figure 3. Asif Quaraishi from Southhall disguising as female in pudah in London (McDermott, 2015).
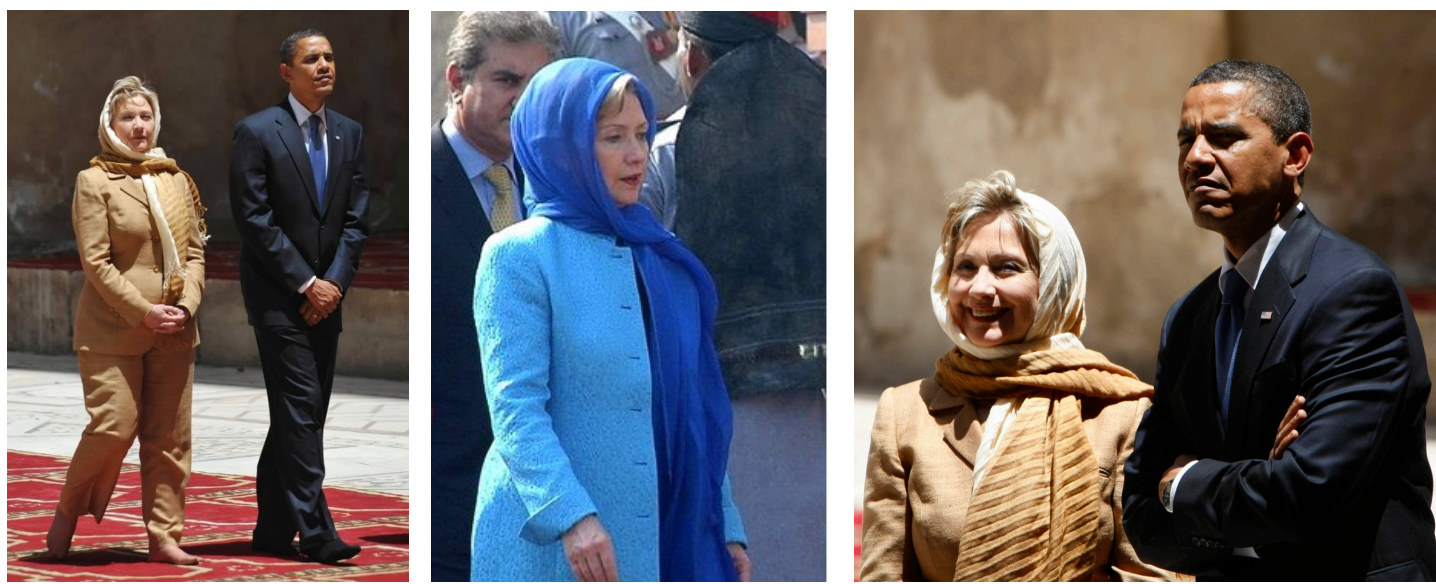

Figure 4. Hillary Clinton with President Obama on three different occasions in the Middle East.

Table 1. State or established religion.

\begin{tabular}{|c|c|c|c|}
\hline S/NO & RELIGION & NUMBER OF COUNTRIES & COUNTRIES \\
\hline 1. & Islam & 25 & $\begin{array}{l}\text { Afghanistan, Algeria Bahrain, Bangladesh, The Comoros, } \\
\text { Egypt, Iran, Iraq, Kuwait, Malaysia, the Maldives, } \\
\text { Mauritania, Mauritius, Morocco, Oman Pakistan, Qatar, } \\
\text { Saudi Arabia, Somalia, Sudan, Emirates, Yemen Republic. }\end{array}$ \\
\hline 2. & Roman Catholic & 11 & $\begin{array}{l}\text { Argentina, Colombia*, Costa } \\
\text { Rican Dominican Republic, Haiti, Panama*, Paraguay+, } \\
\text { Peru, } \\
\text { Seychelles", Venezuela*, }\end{array}$ \\
\hline 3. & Evangelical Lutheran Church & 4 & Denmark, Iceland, Norway, Sweden \\
\hline 4. & Buddhish & 3 & Bhutan, Cambodia (Kampuchea), Thailand \\
\hline 5. & Greek Orthodox Church & 1 & Greece \\
\hline 6. & Judaism & 1 & Israel \\
\hline 7. & Hinduism & 1 & Nepal \\
\hline 8. & Church of England & 1 & United Kingdom \\
\hline 9. & Presbyte-rianism & 1 & United Kingdom (Scotland) \\
\hline 10. & Pancasila & 1 & $\begin{array}{l}+ \text { Indonesia } \\
+\end{array}$ \\
\hline
\end{tabular}

"Quasi: state religion. +: Roman Catholicism is the official religion, although the constitution guarantees religious freedom. +: A national secular state ideology, stressing unity and social justice, which is a compulsory belief for all social organizations. Source: J. Denis Derbyshire and Ian. Derbyshire, (1991) Spotlight on world Political System, Edinburgh: W \& R Chambers Ltd. P. 27. See also Olasupo (2013) "The Role of Arabian and Western Civilization in the Extinction of African Traditional Religion: The Case Studies of Senegal, South Africa and Nigeria" in International Journal of Sustainable Development Canada: International Development Agency. Vol. 05, Issue 12, p. 29. 
capital of unipolar world, has its own monthly contributions of more than 100 foreign fighters. Only recently three teenage girls were turned back from Germany en-route Syria to join ISIS. The problem of what to do with them faces many western governments (Cofflard, 2014; CNN, 2014b). Interestingly but surprisingly, Israeli citizens are also crossing over to Syria to fight for ISIS. "For six months Yakoub Nasrallah and his wife Nahia have been sitting helplessly in their house on the outskirt of the Israeli Arab town of kalansua. Their eldest son, 19-year-old Yussef, left home suddenly one day, without prior notice. He crossed the border to Jordan and from there to Syria. His purpose was to join groups fighting the Assad regime, including Islamic State" (Khoury, 2014).

These are not questions to be ignored if genuine solutions are to be found to the causes of conflicts all over the world. One important thing the western powers have failed to realize is that all what they stand for: Democracy, gender, gay and lesbian rights, western ways of dressing for women etc. are not in conformity with the prescriptions of Holy Quran. Besides, western ways of punishing criminals, female or male, are also at variance with Islamic way of doing the same thing. Punishments such as stoning to death, lashing and beheading are repulsive to western world but acceptable to Islam because they are Quran prescriptions. Unipolar world wants all these modified and modernized as in the case of Islamic way of dressing. Christiana Amanpour and Hala Gorani, female megaphones of the West, demonstrate acceptable modernized way of Muslim women dressing in Figure 5.

Unlike the Christendom that western countries have domesticated to suit their values, it is not possible to transpose this to Islam without undermining the fundamental principles of Islam. Unlike the Bible, Quran is Allah's delivered to mankind and that is why a word cannot be added or subtracted from it without defacing and defaming it. Yes, modernization is necessary but how could this be brought about without violating the sanctity of the Holy Book? The beauty of the Holy land (Makah) today is modernity and technologically driven. Its beauty two thousand years ago was not as exotic as it is today. The weapons that ISIS or ISL uses to prosecute its Jihad are essentially western products as against sword and dagger used in the pre-modern time. So, the issue of modernity in Islam is a complex one that may not be easily won by battles alone.

However, there is an opportunity in the current global coalition against the ISIS or ISL, to encourage modernization in some so called repulsive Islamic doctrines. Never before has Arabian world given massive support for western nations in any campaign against any Arab country or values-Arab-Israeli war of 1967, Israeli-Palestinian war since 1948, American war against Afghanistan (operated under NATO command) 2001, American war against Iraq (operated under NATO command), 2003; Israeli-Gaza war of 2014 - until the current global war against ISL. Influential Arab countries in the current global airstrike campaigns against ISIS include Bahrain, Saudi Arabia, the United Arab Emirate and Jordan. They all joined USA in air raid against Iraq and Syria. Other Arab countries presumed to be part of this coalition but are yet to properly join in the airstrike campaign are Qatar, Egypt and Turkey. Major western powers plus United States of America in this airstrike campaign include: "Britain, France, Australia, Germany, the Netherlands and recently Canada (CNN, 2014c).

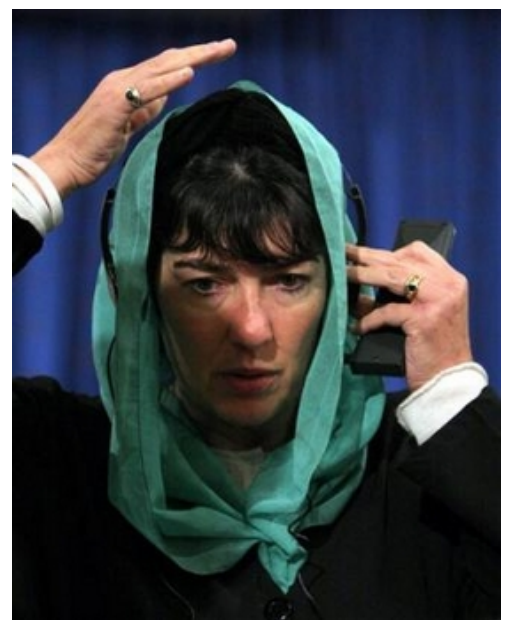

(a)

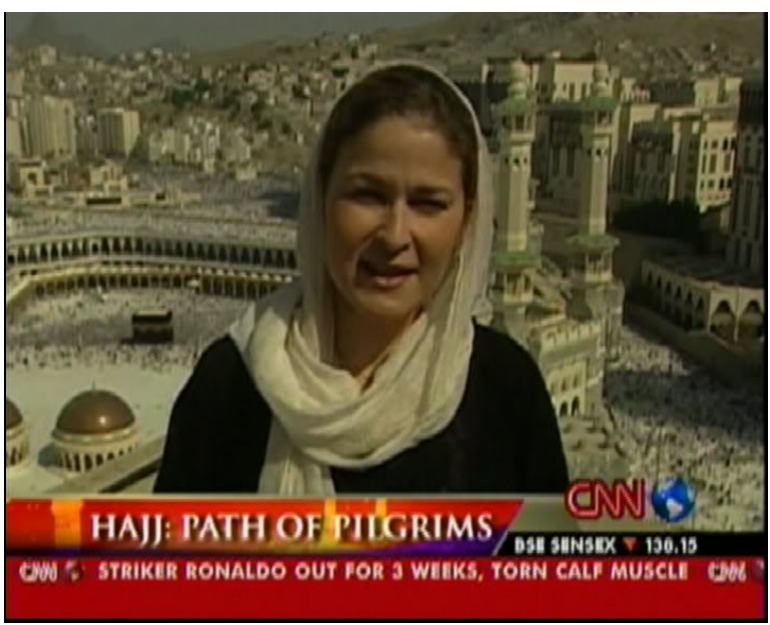

(b)

Figure 5. (a) Christiana Amanpour in Ijab; (b) Hala Gorani in Ijab. 
However, to date, no major country in the Eastern part of the world-Russia and China in particular-has joined the coalition. But it is presumed that these two powerful countries might have given their covert support to the fight against ISIS having also being battling their respective internal terrorists, mostly Muslims. The Syrian government, political ally of Russia China and Iran had said that "it received a letter from USA Secretary of State John Kerry, delivered by the Iraq foreign minister, informing it that the United States and its allies planned to attack ISIS in Syria hours before the raids started". "The United State had previously stressed it would not coordinate with the government of President Bashar Al-Assad in any way in its fight against ISIS" (Mintpress, 2014). But the sudden change of policy by USA therefore might not be unconnected with Russia and China's insistence that connecting Syrian government is a precondition for giving their covert support.

Iran's interest in this war against ISIS is also very interesting to examine here. Iran is one of the backers of Syrian government but also onetime enemy of Iraq especially during the regime of the late Sadam Hussein. Iran and USA have also being long standing enemies since the Iranian revolution of 1979 as well as its presumed development of nuclear bomb. However, "Iran and the United States have found their foreign policies surprisingly aligned in the past several months, both trying to beat back the advance of the Sunni extremists that have gained a foothold in Iraq and war-torn Syria" (CNN, 2014d). Speaking to Christiane Amanpour in an interview, Iranian President, Hassan Rouhani, said of the coalition war against ISIS in Iraq and Syria: "It is a common theatre for all of us. And this requires a unison effort from all of us. We need vast campaign of operations... The aerial bombardment campaign is mostly, I would rather say, a form of theater, rather than a serious battle against terrorism" (CNN, 2014d). Distancing himself from the airstrike "coalition" therefore, he said he would like to "distance himself from the word coalition because some countries haven't come together under the umbrella of this coalition". This may be a tacit reference to Russia and China in particular. So, like Russia and China, Iran also gave covert approval for the war. What is the position of Africa in this airstrike coalition?

No mention, overtly or covertly, is made of African participation in this global war against ISIS but suffice to say that Africa is engaged in its own mini-global war against Al Shabab, which is an affiliate of ISIS or ISL. Al Shabab has for more than six year been tormenting Somalia using Barawe town as a base. Barawe is about 200 kilometer (125 miles) south of Mogadishu and it is a supply route for weapons and food and also a base for lucrative charcoal business. The USA airstrike had earlier softened the ground for Somalia and AU forces. The airstrike killed al Shabab leader, Ahmed Abdi Godane and other senior militants around Barawe. The aim of al shabab is to overthrow the UN backed Somali government and has imposed strict version of Sharia in areas under its control. Besides, only recently a woman was stoned to death in Barawe for alleged adultery. But all these ended when Somali government troops backed by AU forces captured Barawe, the last coastal stronghold of the Al-Shabab Islamist group (News, 2014). Thus, while the developed world concentrate their efforts in tackling ISIS in Iraq and Syria, African Union and special USA force is left to mind al Shabab and Boko Haram in Somalia and Nigeria respectively.

It is interesting at this point to briefly mention the heroic role of women in this global war against ISIS in Iraq and Syria on one hand and African Union against al Shabab and Boko Haram on the other. In the early airstrike against ISIS in Syria, "The United Arab Emirate's first female pilot Major Mariam Al Mansouri, 35, led a mission against ISIS in Syria thus becoming not only the first woman to join the Emirate Air Force but also the first female Arab military officer to participate in the global war against ISIS in Iraq and Syria. The UAE joined the United States, Saudi Arabia, Jordan, Qatar and Bahrain in impending airstrikes against ISIS" (Kim, 2014). While Major Mariam was carrying out her own airstrike campaign in Syria, Nobel Laureate, Malala Yousafzai, after battling Pakistan's Taliban to a standstill, carried out her psychological campaign against Boko Haram in Nigeria, especially over the abduction of Chibok Girls. Taliban and Boko Haram share "anti-western education dogma of Islamic extremists" in common (Effiong, 2014). Currently, these two Muslim Ladies are being celebrated all over the world for their global campaign against extremism in Islamic religion. Figure 6 shows Malala who has just being awarded Nobel Peace Prize and Mariam, the only female pilot in the ongoing airstrike against ISIS, demonstrating acceptable way of Muslim dressing to the West.

\section{Two Systems Approaches}

The current global coalition against ISIS has brought into sharp focus idea of "two systems approaches" to solving world's social, political and economic conflicts, e.g. temporal and spiritual, Muslim-Christian, Israel-Arab (Israel-Palestine), Israel-Gaza, Democracy-Totalitarianism, and Capitalism-Communism. 


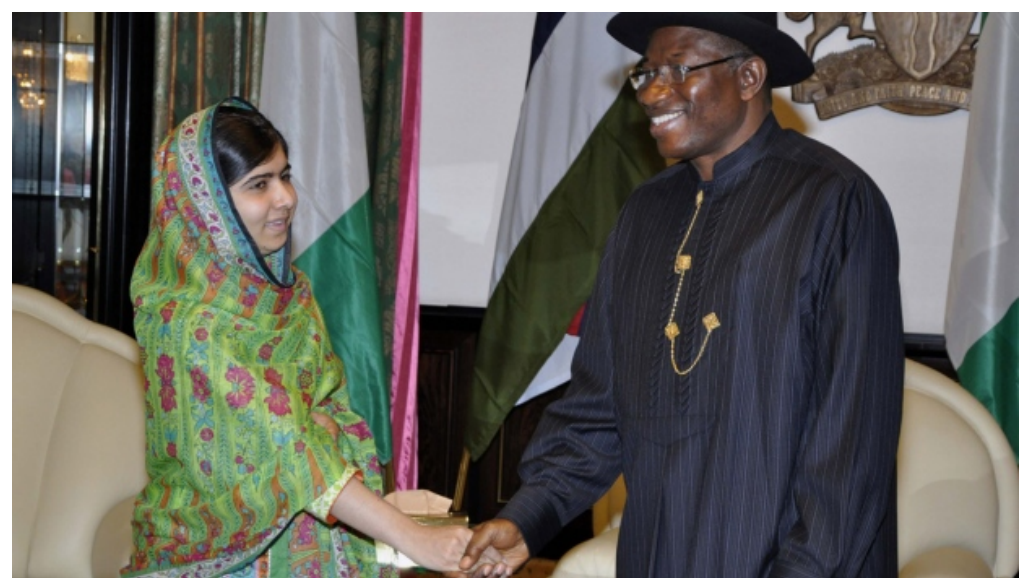

(a)

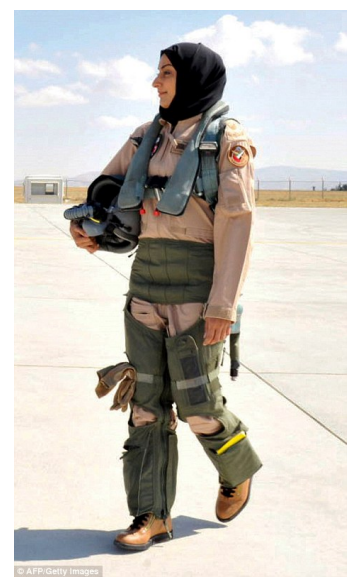

(b)

Figure 6. (a) Malala greeting President Jonathan of Nigeria; (b) Mariam in air force combat dress.

\section{1) Spiritual and Temporal}

Monarchy and Religion formed the first methods of governing men but conflicts between the two led to widening gaps between them. The advent of conquests, colonialism and civilization, particularly from western world, brought the idea of secularity in state affairs. Most, if not all of the western worlds have successfully separated religious life from political ones and have exported this to other nations, especially third world countries through colonialism. Although there are still pockets of theocratic states (e.g. the kingdom of Saudi Arabia and the Holy Sea) in the world today, they are also seeing the need to separate the realm of spirituality from temporal, even if at snail's pace.

\section{2) Muslim and Christian}

Islam and Christianity, though not only religions in the world, are most globally recognized ones and these date back to centuries ago. According to Dalrymple, "In the history of religion, and in the wider story of mankind's yearning to understand its place in the universe "for every book on Mecca there are several shelves on Jerusalem; for every study of the Hejaz, there exists a groaning library on the Holy land"; thirdly and finally, Mecca is almost as important a site as Jerusalem. In Jerusalem, there is a religious site which both Jews and Arabs are entitled to pray. It contains a compound known to Jews as the Temple Mount, and to Muslims as Haram al-Sharif. It is the holiest site in Judaism, and also contains the al-Aqsa Mosque, the third holiest site in Islam (News Sections, 2014b). Mecca is also remembered as a place of pilgrimage in the Bible, under its earlier name of Baca: "Blessed are those... who have set their hearts on pilgrimage, reads Psalm 84. As they pass through the valley of Baca, they make it a place of springs". In fact, it said that by the side of Prophet Mohammed's grave, a portion of land is preserved for the second coming of Jesus Christ, so that when he finally dies, he would be buried there.

However, given all these, as Dalrymple puts it "yet in English it is still virtually unwritten" and "there are a few Victorian travelogues" save Sir Richard Burton who disguised in his walnut greasepaint and turban" and travelled to Mecca (Dalrymple, 2014). This explains the fact that in the beginning there was intercourse between Islam and Christianity. The Jews through Jesus Christ gave the world Christianity while Arabs through Prophet Mohammed (SAW) gave the world Islam.

But within nation-states today, especially in the third world countries, votaries of these two famous religions regularly clash although there has not been a global example of this. However, ISIS almost brought it about when its Jihadist activities led to massacre of many Iraqi Christians that led to an outburst from Pope Francis. According to the Pope, "it would be legitimate for the international community to use force to stop "unjust aggression" by Islamic State militants who have killed or displaced thousands of people in Iraq and Syria, many of them Christians (Rellandini, 2014). This outburst from the Pope did not anger prominent Arab leaders otherwise the situation would have degenerated to global Muslim-Christian war.

Arab allies of western powers are all profoundly threatened by Islamic State and have an incentive to openly align themselves with the world's only super power (Feeds, 2014). The division in the Arab solidarity has a short story. Egypt started it when it unilaterally signed Camp David accord with Israel in 1979. In the 1990/91 
coalition that battled Saddam Hussein, few Arab nations participated and this is significant otherwise Saddam and his supporters would have claimed this "was purely a western imperialist war" (Feeds, 2014). Against ISIS however, ten prominent Arab nations participating in the coalition include Saudi Arabia, Bahrain, Egypt, Iraq, Jordan, Kuwait, Lebanon, Oman, Qatar and the United Arab Emirate (Times, 2014).

By these, The Holy Sea and Kingdom of Saudi Arabia are united against ISIS, and so are what the two stands for-Islam and Christianity. The unity is a spiritual one that needs to be supported by physical one. The United Nations should consider these two powerful religious leaders as members of Security Council on religious grounds only. Whenever the United Nations Security Council is considering issues of global peace, these two persons should be invited. King Fahd is already a member of G20, which the Pope is not; not because Pope is discriminated against but because the Holy Sea is not a global economy player in the sense in which Saudi Arabia is. In Figure 7 are the pictures of the patriarchs of the two most powerful religions in the world.

In the Arab world, Egypt appears to be pathfinder in this cross-religious unity. In Egypt for instance, one of the country's oldest Coptic Christian churches, Virgin Mary church in Cairo, also known as the hanging church because it is seated above a 2nd Century Roman fortress, has been completed. It used to home the Coptic pope until the 13 Century. The church is in a compound close to Cairo's first mosque and one of the oldest synagogues; thus completing the trinity unity of Islam, Christianity and Judaism. The opening ceremony was attended by Prime Minister Ibrahim Mahlab and Coptic Pope Tawadros II. On the occasion too, "President Abdel Fattah al-Sisi called for Christians and Muslim to be united" (News Sections, 2014b).

As a matter of fact, Christians are the ones providing political stability for the recent internal conflict between two conflicting Muslim administrations in Egypt-Abdel Fattah al-Sisi military administration and the defunct democratically elected civilian administration of President Mohammed Morsi. Despite damage to dozens of Christian churches last year during the course of the conflict between the military and the civilian administration of Morsi, many Christians, up till today, are sympathetic to the overthrow of President Morsi (News Sections, 2014b). They are also the ones providing unalloyed support for the current camouflaged military regime of President Abdel Fattah al-Sisi.

\section{3) Israel-Palestinian}

Part of the positive fallout of the current global airstrike coalition against ISIS is the issue of "two state solution" to age long Israeli/Palestinian conflict. Sweden has become the first long-term EU member country to recognize the state of Palestine. According to the new Swedish Prime Minister, Stefan Lofven, "the conflict between Israel and Palestine can only be solved with a two-state solution". "It should be negotiated in accordance with international law", he said (News Sections, 2014b). In Britain, the House of Commons has also recently voted in favour of recognizing Palestine as a state alongside Israel, although the result of the vote, 274 to 12 is largely symbolic but could have international implications. Unlike in Sweden however, "government ministers abstained on the vote, on a motion put forward by Labour MP Grahame Morris and amended by former Foreign Secretary Jack Straw" (News Sections, 2014c).

Defining "two-state solution", the new Prime Minister of Sweden said "a two-state solution requires mutual recognition and a will to peaceful co-existence. Sweden will therefore recognize the state of Palestine. Expressing similar position, current UK government states that it "reserves the right to recognize a Palestinian state bilaterally at the moment of our choosing and when it can best help bring about peace". Following UK in passing

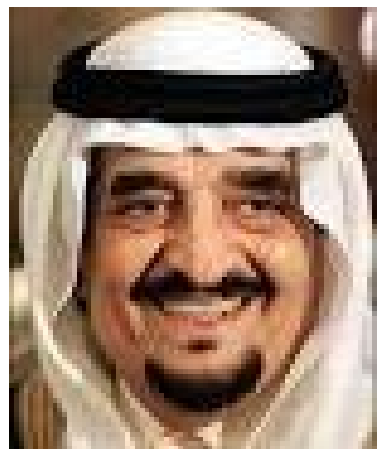

(a)

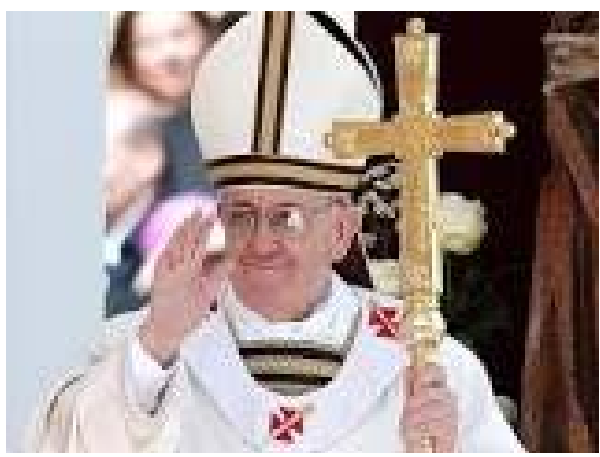

(b)

Figure 7. (a) King Fahd of Saudi Arabia; (b) Pope Francis of the Holy Sea. 
non-binding motion are Ireland, Spain, and France. For some time there was no definitive EU position on this, as most of the EU's 28 member states had refrained from officially recognizing Palestinian statehood. Though some EU member countries, such as Hungary, Poland and Slovakia recognize the state of Palestine; they had done so before joining the bloc (News Sections, 2014d).

There is however, a recent acrobatic change of position when "the European Parliament voted to recognize Palestine as a state 'in principle', by overwhelming majority of - 498 in favor and 88 against". There was a standing ovation in the chamber at this result, as many feels this is a historic moment: it's the first time that the parliament has adopted a formal position on the issue. The vote was in support of three important contentious areas of disagreement between Israel and Palestine: Palestinian statehood, two-state solution and Jerusalem as the capital of both states. The vote also emphasized that those "Israeli settlements are illegal under international law and calls on EU to become a facilitator in the Middle East peace process (News Sections, 2014d).

Adding their voices to this ongoing debate on "two-state solution" Mahmoud Abbas of Palestine and Abdul Fattah al-Sisi of Egypt "urged Israel to give up land seized in the 1967 Middle East war and accept a fair solution for Palestinian refugees in exchange for full recognition". These, according to them, would ensure "a longterm peace initiative" (News Sections, 2014e).

\section{4) Israel-Gaza}

The recent global coalition efforts to solve some global problems have been extended to Israel and Gaza conflict. Gaza strip is sandwiched between Israel and Egypt and has been a recurring flashpoint in the Israeli-Palestinian conflict for years. Gaza became occupied by Israel in the 1967 Middle-East war. But Israel pulled its troops and settlers out in 2005, giving the impression that is the end of the occupation. However, it (Israel) still exercises control over most of the Gaza borders, waters and airspace. Egypt also controls Gaza's southern border (News Sections, 2014e). After 50-day or seven-week conflict between these two conflicting neighbors it is now time to rebuild the damaged infrastructures in Gaza. The seven-week conflict, which ended in a truce on 26 August, killed more than 2100 Palestinians, most of them civilians, lost 18,000 homes and more than 100 schools. On the Israeli side were 66 dead soldiers and seven civilians' losses (News Sections, 2014e). The two sides have fought three wars in six years but the recent and the last one was the most devastating in both human and material resources. This necessitated the need to convene international conference to tackle the rebuilding of Gaza infrastructures as well as thousands of civilian homes destroyed. Supporting the idea of global response to devastated Gaza, Mahmoud Abbas and Abdul Fattah al-Sisi reiterated that Israel "give up land seized in 1967 Middle East war and accept a fair solution for Palestinian refugees in exchange for full recognition" (News Sections, 2014e). Some months earlier, Palestinian rivals - Fatah and Hamas - had united to replace two administrations - one headed by Mr. Abbas in parts of the West bank and the other led by Hamas in Gaza, with one headed by Mr. Abbas.

The conference was attended by UN Secretary-General, EU foreign policy chief Catherine Aston and envoys from dozens of countries, which was hosted by Egypt's President Sisi. At the conference, Palestine had requested for 4 billion dollars to rebuild Gaza. Out of this Qatar promised to donate \$1 billion, USA \$212 million, and UK $\$ 32$ million. "The total, announced by the Norwegian Foreign Minister, Boerge Brende, exceeded the $\$ 4$ bn the Palestinian Authority had asked for (News Sections, 2014f). This is regarded as "a major breakthrough, a very important signal of solidarity to the Palestinian people in general and not least to the people that are suffering so badly in Gaza". Israel that was not invited to the conference however said any rebuilding efforts would need their government's support. "You can't reconstruct Gaza without Israel participation and without Israeli co-operation".

Is this, again, possible without Russia's involvement, given Henry Kissinger's interview with Amanpour? This is Henry Kissinger's summation: "In the end, we and Russia can develop common objectives because where we clash are issues like Syria, where I believe we both should have the same objective, which is the radicalization of the Arab world. Because a radical Arab world will spread over into Russia before it spills over into us" (CNN, 2014c)

\section{5) Jerusalem and East Jerusalem}

The tension in east Jerusalem today has potentiality of snowballing into global conflict because of its holiness. For a long time, the fate of Jerusalem has been one of the most contentious issues between Israel and the Palestinians. The Palestinians want East Jerusalem as the capital of a future state, while Israel regards the whole of Jerusalem as its "eternal and indivisible capital" (News Sections, 2014g). Until 1967, East Jerusalem was part of Palestine but Israel occupied East Jerusalem in the 1967 Middle East war and annexed it in 1980 in a move not 
recognized internationally. Added to the complexities of East Jerusalem, is that it contains a compound known to Jews as the Temple Mount, and to Muslims as Haram al-Sharif. It is the holiest site in Judaism, and also contains the al-Aqsa Mosque, the third holiest site in Islam (News Sections, 2014b). However, violence in the area surged recently when Rabbi Glick, a well-known USA born campaigner for the right of Jews to pray at the site was shot and wounded. Israeli police in return killed a Palestinian suspect who shot the Rabbi. Until now, Jews were prohibited by Palestinian Arabs from praying there (News Sections, 2014b).

Violence soon began to escalate as a Palestinian driver rammed a van into several pedestrians, killing a policeman and wounding 13 other people. A similar car attack by a Palestinian took place in the same area two weeks earlier, leaving behind dead woman and a baby. The violence resurged again, this time in west Jerusalem, when two Palestinians with guns and meat cleavers hacked four rabbis to death "at a time of prayer" before they (the two Palestinians) were also shot to death (News Sections, 2014h). A policeman also, later, died of his wounds. The four rabbis hacked to death were Moshe Twersky, 59, head of the seminary; Arieh Kupinsky, 43; and Kalman Levine, 55, all of whom who also held USA passports. The fourth victim, Avraham Goldberg, 68, was also a UK citizen.

The conflict between Israel and Palestinians "used to be, at root, about possession of land. But since Israel captured West Bank, including East Jerusalem, in 1967, it has become more defined by religion. Perhaps that was why the Palestinians chose a synagogue for the attack that killed the four Jewish worshipers" (News Sections, 2014h). The critical questions here are: why are the four victims' holders of USA passports and British passport respectively? Why are they from unipolar world, particularly the two important centers of unipolar world - USA and UK? Why were there no indigenous orthodox Jews among the victims or at the prayer site at that time? Why is it that the campaigner for the rights of the Jews to worship at Temple Mount an American?

This situation is getting international dimension as "Jordan has recalled its ambassador to Israel over what it called the 'unprecedented Israeli escalation' at holy and sensitive sites in Jerusalem". In a similar but unrelated dimension, a Pakistani Christian couple was killed recently by "beating and pushed into burning kiln in a village of Kot Radha Kishan eastern Pakistan. They were accused of desecrating the Quran (CNN, 2014f). And in Kenya, al-shabab gunmen attacked a bus slaughtering 28 people (19 men and 9 women) out of the 60 passengers who were all non-Muslims. The bus was travelling to capital Nairobi, when it was stopped in Mandera County, not far from the border with Somalia. The Gunmen separated out non-Muslims by asking passengers to read from the Koran. Those who failed were then shot in the head". Not long after this, additional 36 non-Muslim quarry Kenyan workers were gruesomely murdered near the north Kenyan town of Mandera. While some were shot at close range in the head, "four were beheaded inside their tents but three escaped" (News Sections, 2014i). Again, the attackers from the al-Shbab group shot the non-Muslims dead after separating them from Muslim. Seeing this as a clear effort of igniting religious war between Muslims and Christians, a senior government adviser to President Uhuru Kenyatta, Abdikadir Mohammed, called Kenyan of faith and creeds to stand together against the heinous crime. According to him, "the aim is to create conflict between the Muslims and the non-Muslims in this country". "The aim is to create a religious war, religious strife, in Kenya" (News Sections, 2014j).

This internationalization of "piece meal" wars are worrisome and like Pope Francis said, they are traceable to nothing other than "greed, intolerance and the lust for power; these motives underlie the decision to go to war and they are too often justified by an ideology", Pope Francis said. The holy site that has been existing from time immemorial and that tolerated co-existence of both Jewish Temple and Mosque, how come it suddenly becomes focus of religious intolerance between the Jews and Arab Palestinians? For a long time too, the site has served as pilgrimage for not only worshipers of Judaism and Islam but also Christians worldwide. Jerusalem should have served as effective melting pot of all religions, particularly Islam, Christianity and Judaism but greed, intolerance and lust for power among politicians and religious leaders are behind this disunity.

\section{6) Jerusalem and Bethlehem}

These two important holy lands with three different religions: Judaism, Islam and Christianity are united by one person-Jesus Christ who was born a Jew in Arab land, Bethlehem, the cradle of Christianity accepted mostly outside Jewish and Arab lands. In the beginning the three religions co-habited peacefully but today, one of the contending religions, Christianity, is under extinction in the region, especially Arab lands of Iraq and Syria where ISIS is "pushing some of the world's oldest Christian communities out of their homes in northern Iraq. For some, the choice was converting to Islam; pay a special tax, leave or die. So instead, tens of thousands fled to Kurdistan. There they remain, sheltering in churches and schools with few possessions" (News sections, 2014k). A new dimension is being added to this. Israel is building barrier "around the West Bank, which sepa- 
rates Bethlehem from Jerusalem". Explanation provided by Israel for this was to prevent attacks by militants. Butif this barrier were there when Christ was born, would it have been possible for Marry, mother of Christ, to cross over from Jerusalem to go and deliver at the Manger and thereby erecting bridges of religious, holiness and territorial peace. Jerusalem may be holier than Bethlehem, but "there are Bethlehem's biggest two days of the year - the one occasion when, for Christians, it displaces Jerusalem". These two days are the eve of the Christmas when Marry fell into labor and the Christmas day when Christ was born, a point Pope Francis made he visited earlier this year (News sections, 2014k).

\section{7) The Jews and Arabia}

"It's well-known that Jews once lived all across Arabia". The Koran records Jewish tribe in and around Medina in the 7th Century, and the medieval traveller Benjamin of Tudela, who passed through in about 1170, describes sizable Jewish populations throughout modern day Iran, Iraq and Saudi Arabia, as well as on both shores of the Gulf-at Kish (Iran) and Qatif (Saudi Arabia. Baghdad had been home to Jews since the 6th Century BC. Around the time of WW1, officials estimated the city's Jews to number between 55,000 and 80,000 - a proportion equal to or greater than those in centers of European Jews such as Warsaw or Berlin (News sections, 2014l).

"Today, fewer than 10 individuals remain". In Iran perhaps 25,000 Jews remain, while Bahrain has a tiny Jews minority, comprising only few families - though they wield significant power. Until last year, Bahrain's ambassador to the USA was a Jewish woman, Houda Nonoo".

However, "for a combination of reasons including" as Pope Francis observed, "economic migration, political pressure and outright persecution - notably after the State of Israel was declared in 1948-almost all the Jews communities of the Gulf countries dwindled to nothing in the 20th Century" (News sections, 20141).

\section{8) Vatican and the Chinese}

"The Vatican and the Chinese government have been at odds over control of the Catholic Church in China. Christianity in China goes back to the 7th Century - many have been forced to practice in underground, illegal churches". "There are many restrictions for the official Church, such as the requirement to register all church buildings with the government, and being unable to recognize the authority of the Vatican" (News sections, 2014m).

"The Chinese Communist Party oversees an official community, known as the Patriotic Association and believed to number about 12 million people, but there is also a much larger underground Church that is loyal to the Pope". So, the "serious bone of contention between China and the Vatican is which side should have the final say in the appointment of bishops.

What brought this issue up recently was the issue of Dalai Lama who requested to pay visit to Pope Francis while in Rome to attend meeting of Nobel Peace Prize Winners; initially slated for South Africa but had to be relocated to Rome because South Africa refused Dalai Lama visa. Similarly, Pope Francis does not want to jeopardize efforts to improve relations with China, hence the turned-down of Dalai Lama request to pay visit to the Pope.

Dalai Lama is described by China as separatist and reacts angrily when foreign dignitaries meet him. He fled to India in 1959 after Chinese troops crushed an attempted uprising in Tibet. However, Dalai Lama now advocates a "middle way" with China, seeking autonomy but not independence for Tibet. Has awarded the Nobel Peace Prize in 1989 (News sections, 2014m).

\section{Democracy}

This is another important issue that can plunge the world into third world war and, perhaps, the first thermonuclear war. Elements under this include openness (or what Russians call glasnost) in electoral and judicial process; restructuring (or what the Russians call Perestroika); human Right issues and policing. The unipolar world and its allies no doubt have the highest standard of all these elements having been originated and developed there. For decades, in fact, centuries, they have been marketing these to the entire world, most often using military and economic forces.

\section{1) Electoral and Judicial Process}

Transparency in the choice of who leads a country in the western world is no longer a secret affair. Competitors for public offices are seen campaigning for votes, electorates are seen voting, voting is counted openly, and the winner is declared and sworn in openly. This is not the case in the communist world. They have their own version of democracy that is not as transparent a as those of the Westerners but a democracy all the same. Take 
the case of Hong Kong for example.

a) Hong Kong

Hong Kong operates under a "one country, two systems" arrangement with Beijing, which means citizens are allowed the right to protest. So, "China rules Hong Kong under a formula that accords the former British colony a degree of autonomy and freedoms not enjoyed in mainland China" (Brunnstrom \& Wroughton, 2014). In August this year however, Beijing decided that candidates for chief executive election would first have to be approved by nomination committee perceived to serve the Chinese communist party (News Sections, 2014n). The Students, on the other hand wants to pressure China into giving Hong Kong full voting rights and the ability to choose candidates independent of Beijing (CNN, 2014g).

As USA and its political and military institutions began to fish in Hong Kong crisis by given support to democracy activists, China warned against other countries interfering or "sending the wrong message to protesters" (Brunnstrom \& Wroughton, 2014). Reacting to this, President Putin says "the world is becoming an increasingly dangerous place because of USA attempts to enforce its will on other countries and that his nation will not comply" (Isachenkov, 2014). He warned that "if the United States fails to abandon its desire of eternal domination", then "hopes for peaceful and stable development will be illusory, and today's upheavals will herald the collapse of global world order" (Isachenkov, 2014). Further accusations by Putin against headquarter of unipolar world, USA, is its "support for dubious elements from open neo-Nazis to Islamic radicals instead of democracy". Recent "declassified USA records reveal the nation's intelligence used hundreds of Naziz as spies and informants after World War Two". The declassified information states that "central Intelligence Agency officials are said to have turned to the country's former enemies to help beat the Soviet during the cold war". Academics studying the documents says America used at least 1000, ex-Nazis (Isachenkov, 2014).

In the area of judicial process of other countries, again, USA is found wonting, using its own system as benchmark. While transparency in most of its operations, institutions and systems are commendable, other nations, particularly her ideological rivals, are often secretive and therefore incredible, but then, they deserve democratic rights to adopt a system that suits their own political systems and environments too. When they are politically matured enough to practice the kinds of sophistications in transparency used-to in western world they shall do so on their own free will rather than for the western world to stampede them. Again, this does not mean the west should not criticize but it should be devoid of coercion as they are currently doing in the case of Russia. For example the defeat of communism by capitalism in 1991 was neither through internal nor external forces. Rather, former President Gorbarchev's policy of glasnost and perestroika brought down communism and the political disintegration of Soviet Union (Steele, 2011). Two cases of judicial processes, judgments and executions found outrageous in the Western world of recent were the case of Jang Song-Thaek, 67, of North Korea along with five close aids, and the case of an Iranian woman who killed a man she said was trying to sexually abuse her, Reyhaneh Jabbari, 26.

b) Macau

Like neighbouring Hong Kong, Macau, a short ferry ride away from Hong Kong, is a special autonomous region and former Portuguese colony returned to China. Early this year it experienced protest by pro-democracy activist. Just like in Hong Kong, "six months ago, demonstrators in Macau took to the streets to demand greater democracy", because Mr. Chui was the only nominee for the chief executive position, and was elected by a 400-person panel. Macau's people's protest was thus against Beijing's principle of nominating candidates out of whom the people could vote for; because "Beijing does not want the territories to become hotbeds of dissent". In any case while this policy succeeded in Macau to the extent that when Mr. Fernando Chui was being inaugurated as Chief Executive, President Xi Jinping attended the inauguration ceremony. On the occasion Jinping Xi reiterated the fact that "we must both adhere to the 'one China' principle and respect the difference of the two systems" (News sections, 20140).

c) North Korea

In the case of Jang Song-Thaek, there was no open accusation by the State against him, no open trial, no open judgment and no open execution. The lack of openness led to a lot of speculations not only in western world but more importantly in China and India, the two Asian giants.

According to a Chinese newspaper, "North Korean leader Kim Jong-un did not execute his uncle, and political second in command, by firing squad as has been widely assumed, but by feeding him and a group of others alive to pack of 120 wild dogs". Jang Song-Thaek, 67, along with five close aides, was stripped naked and 
thrown into a cage of hounds which had been starved for three days (The Commentary, 2014). The Indian Express newspaper, which follows developments in China closely, added: "The pack of animals spent more than an hour mauling the group in a punishment called "quan jue", or execution by dogs... The entire process was supervised by Kim, 30, along with 300 senior officials, the paper said" (The Commentary, 2014).

d) Iran

In the case of Reyhaneh Jabbari, 26, what the West, through one of its monitoring institutions, Human rights group Amnesty International, complained about is not the execution per say but the judicial process towards the execution. That, she was convicted after a deeply flawed investigation; and disregarding "a campaign calling for a halt to the execution on Facebook and Twitter that appeared to have brought a temporary stay of execution" only to be suddenly executed on Saturday (News Sections, 2014p). USA and allies as global police of the world caught Iranian government on this. Figure 8 is the executed Jabbari demonstrating acceptable way of Muslim dressing to the West.

Another case of human rights violation in Iran repulsive to unipolar world is the case of "a British-Iranian woman detained in Iran after trying to watch a men's volleyball match" and had to be "sentenced to a year in prison". Ghoncheh Ghavami, 25, was found guilty of spreading anti-regime propaganda, lawyer Alizadeh Tabatabaie said. Iran banned women from volleyball games since 2012, extending a long-standing ban on football matches (News Sections, 2014p).

The argument of Iranian authorities is that "women need protection from the lewd behavior of male fans". Reacting to the sentencing of Ghavami who is from Shepherd's Bush in west London, British Foreign office said "we have concerns about the grounds for this prosecution, due process during the trial and Miss Ghavami's treatment whilst in custody". An arm of the unipolar world, Amnesty International also describe her "a prisoner of conscience, and called for her immediate release. More than 700,000 people have signed an online petition urging the authorities to free her" (News Sections, 2014p).

After persistent pressure from hundreds of thousands of people who signed a petition calling for her release coupled with Ghavami's personal hunger strikes against her detention, freed after serving five months of a oneyear sentence (News Sections, 2014q). Figure 9 shows jailed British-Iranian journalist for watching volley ball being played by males. Also, she demonstrates acceptable way of Muslim women dressing to the West.

e) Saudi Arabia

Saudi Arabia is currently the focus of Women's rights crisis and this has attracted not only the attention of Human rights organization but that of the entire glob as well. The issue of Saudi women's right to drive is the focus of the international community right now. On 30 November this year, Saudi activist, Lujain Al-Hathlool, "filmed herself driving in the United Arab Emirates with the intention of crossing the border back to her home country as part of the '26 October' campaign, which challenges the Saudi ban on female drivers. The video has had over 800,000 Views and over 3000 comments on You Tube he video". She also documented her journey on Twitter, saying "follow me to find out what will happen at the border". Arriving at the border with Saudi Arabia, she live-tweeted the moment when she was stopped by a Saudi customs officer at the border.

After twenty-four hours spent on the border of Saudi, Al-Hathlool tweeted to her 233,000 followers on 2 December. "They won't give me back my passport and they won't let me pass through and no word from the Ministry of Interior. Complete silence from all the officials". This has ignited another round of global debate, both for and against women drivers in Saudi Arabia. Human rights Watch has stepped in and is calling on Saudi authorities to release the two women-Al-Hathlool and her female friend journalist, Al-Amoudi (BBC, 2014). Figure 10 of the activist Al-Hathlool also shows acceptable way of Muslim dressing to the West. Note that in all the figures so far mentioned in this paper, there is none in purdah or veil.

f) USA

Justice system in the United State of America, the world's benchmark, came under sever attack by one of its own minority races - blacks - leading to caustic and corrosive United Nations (UN) intervention. In a row, five black people-Trayvon Mrtins, Michael Brown, Tamir Rice, Akai Gurley and Eric Garner were murdered by five white policemen. These all black men's controversial deaths made national and international headlines (Jones, Almasy, \& Sanchez, 2014). Equally intriguing is none indictment or punishment of any of these trigger-happy white policemen. Culpabilities of the five Grand juries in these cases are also appalling necessitating UN damnation of USA justice system. Accordingly, "UN human rights experts have expressed 'legitimate concerns' about USA juries failing to charge policemen involved in the deaths of two black civilians"; saying "it is part of a 


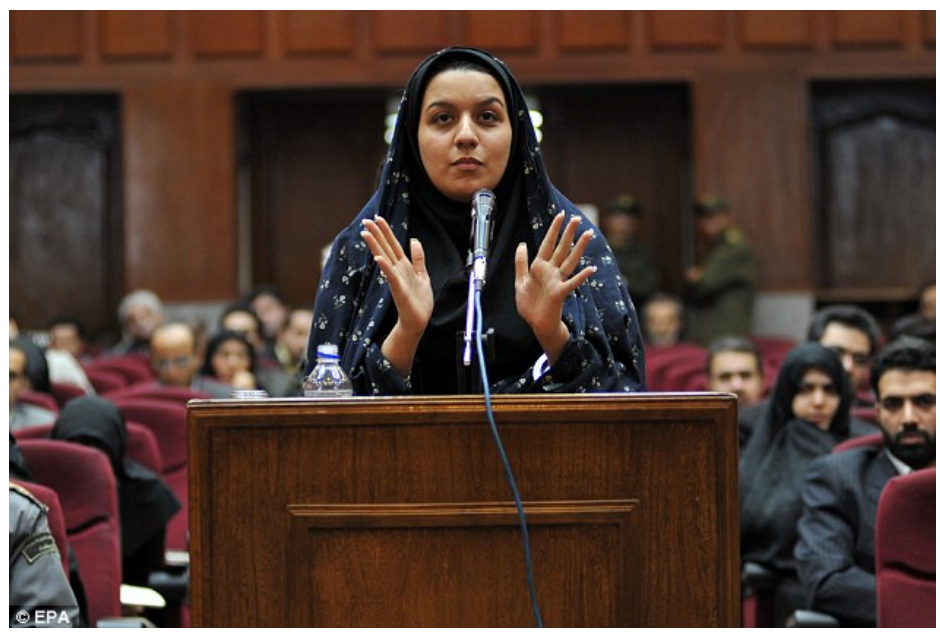

Figure 8. Reyhaneh Jabbari addressing the court before her execution despite Human Rights organizations appeal for clemency.

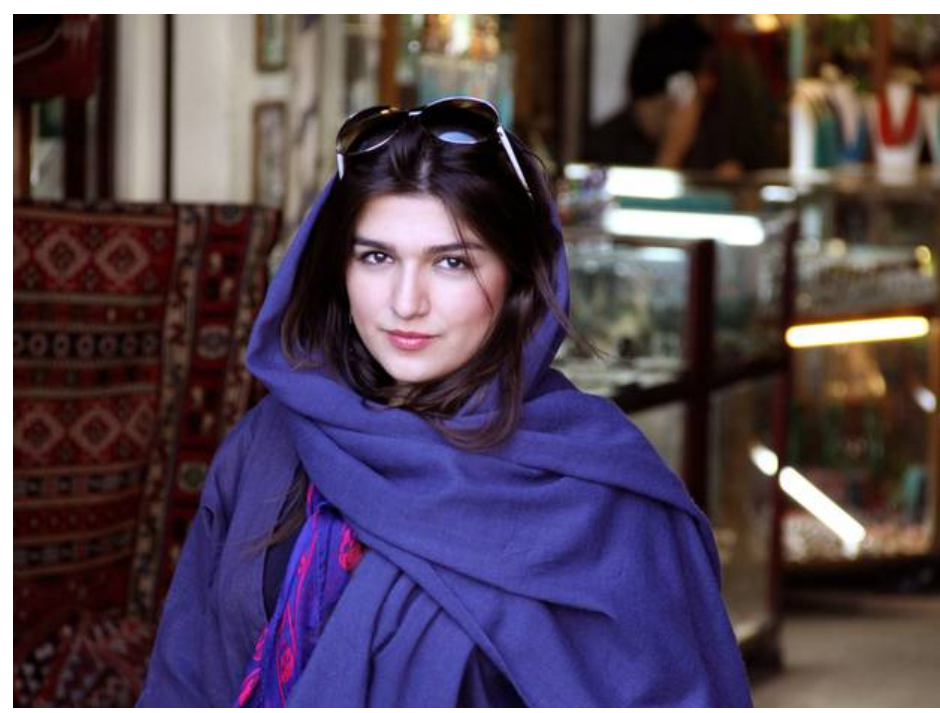

Figure 9. Ghoncheh Ghavami could face six years in prison over fresh charges.

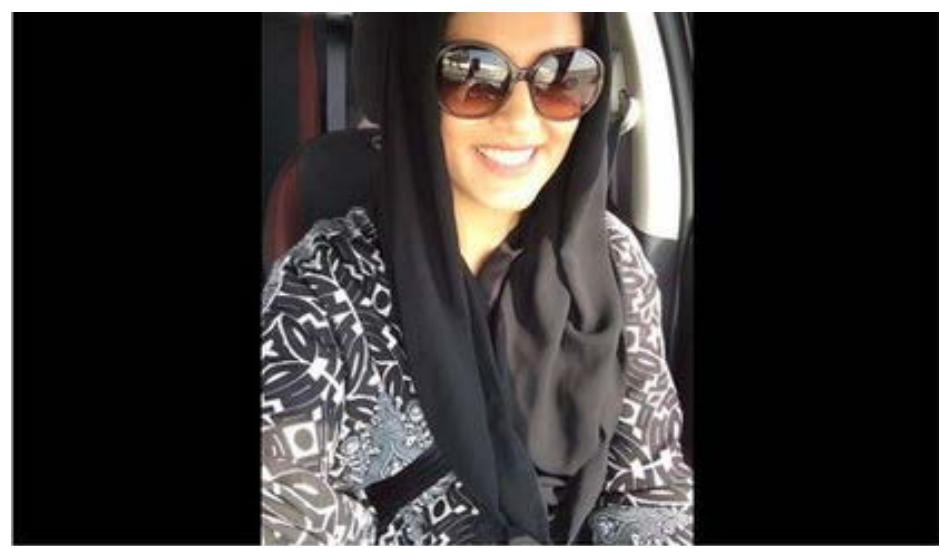

Figure 10. Al-Hathlool, the Saudi Arabia women driver activist detained at the border between United Arab Emirates and Saudi Arabia. 
broader 'pattern of impunity' concerning minority victims". Categorically, it further states that Grand juries in Missouri and New York failed to charge either officer. As UN Special Rapporteur on minority issues, Rita Izsak, puts it "I am concerned by the grand juries' decisions and the apparent conflicting evidence that exists relating to both incidents" (News Sections, 2014r). Could all these be a way of getting at Obama?

In the last three months or so there have been two intrusions in on to the North Lawn of the white House first by Dominic Adesanya, said by his father, Victor Adesanya, to have mental disturbance that causes him to hear voices. Before, Adesanya was another by Texas resident Omar Gonzalez who scaled the fence on 16 September (Ateku, 2014). Armed with a knife, he managed to enter the White House before he was stopped by secret service agent. Though this is not limited to Obama's presidency, it is more frequent under his administration. For instance in February 2004, Brian Patterson from New Mexico jumped over the fence while shouting that he had been victim of terrorism. On 4 December 2005, 29-year-old Shawn Cox did so in search of Chelsea Clinton, whom he wanted for a bride. In short, to date, there has been not less than 15 previous White House fence-jumpers in the last five years with six of those happened during Obama's presidency (Ateku, 2014). See Figure 11 for the UN depiction of racial profiling against blacks in the USA.

\section{2) USA and Policing}

It is interesting to observe that the issue of USA and allies as global police has crop up again; this time from inside America itself. In my earlier write-up, I did argue for why America is eminently qualified to be the patent global police given its unrivaled Democracy, Human rights records and huge resources - human and material (Olasupo, 2014). However, that is not to say that American policing role should not be policed too. Russia and China have what it takes to do that. However, recently, Dr. Henry Kissinger raised dust over this. "We can't be the world's policeman" he told Amanpour, "but we can be the world's last resort" (Krever, 2014). For him, Kissinger, "the last resort" means "but in the last resort, and if the issue is important enough, the United States may have to act-for the sake of everybody" (Krever, 2014). I disagree with Dr. Henry Kissinger on this. In a World cup, red card is always the last resort but often proceeded by two or more yellow cards by the same referee and his/her subordinate linesmen or women. Even where the referee and his/her linesmen or women, by omission or commission, do not spot infringement, spectators do cry foul.

Justifying the pre-eminence of unipolar world and it head, USA, Ban Ki-Moon, United Nations' SecretaryGeneral, recently blasted some world leaders for their poor response to Ebola epidemic. Here him, “... The same cannot be said of others among the world's most influential countries, whose miserly and irresponsible reaction to the epidemic belies their claims to the 21 st century global leadership" (Tisdall, 2014). This is a tacit reference to China in particular whose paltry $\$ 38$ million and later additional $\$ 16$ contribution to Ebola finance solution is damnable given its huge investments in Africa and more importantly being "the world's second largest economy and would be global leader with extensive commercial interest in Africa"; although, it further promised it "would help train African healthcare workers and supply medical kits and ambulances. In contrast, USA, China's global economy rival, announced an additional \$142 $\mathrm{m}$ in humanitarian aid, on top of its extensive previously announced, military and other multilateral assistance" (Tisdall, 2014).

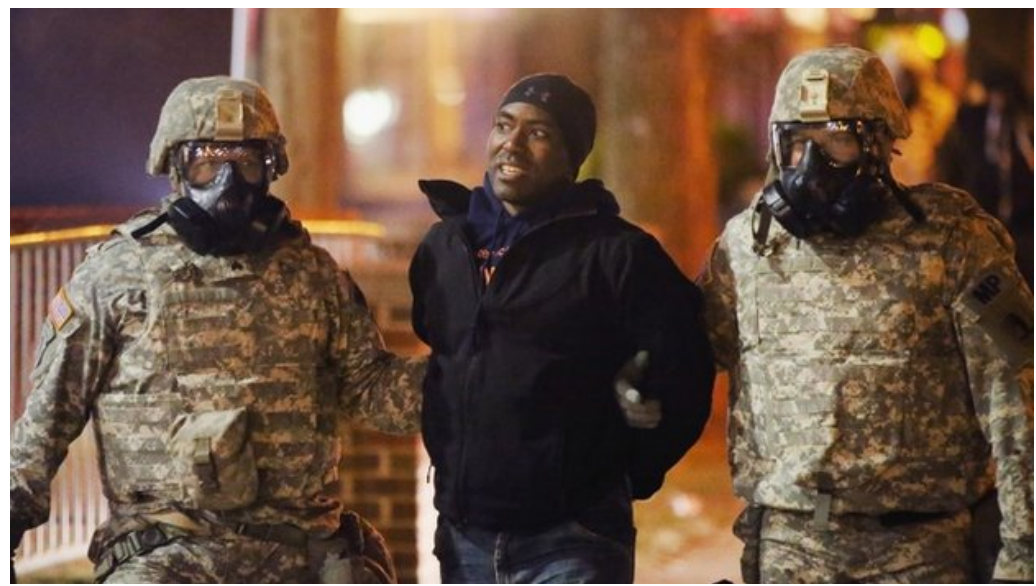

Figure 11. United Nations depiction of black racial profiling (News Sections, 2014r). 
Africa and China had entered into a new era of friendship when on 28 January 2012, China, through one of its most senior political advisers, attended the inauguration of the newly built but China funded African Union headquarters in Addis Ababa. "The entire $\$ 200 \mathrm{~m}$ (one hundred and twenty seven million pounds) project was funded by China as a gift to the AU, as Beijing continues to strengthen its influence in Africa" (BBC, 2014a). In its speech at the inauguration, "China's most senior political adviser, Jia Qinglin said "The towering complex speaks volumes about our friendship to African people, and testifies to our strong resolve to support African development". But the donations of just, $\$ 38 \mathrm{~m}, \$ 16$ and later $\$ 5$ million to fight Ebola epidemic ravaging Africa belies the eulogies made above. What is five million dollars compared with two hundred million dollars funded AU headquarters in Addis Ababa? Which matters most: African building or African health? Sick persons leave in the hospital and not in the gigantic building like African Union headquarters in Addis Ababa. Africa is currently seriously ill and it is a contagious illness that whether you like it or not you will share from unless you do not have investments in Africa. Africa is currently in hospital and not in your funded African Union headquarters.

"Notwithstanding President Vladimir Putin's repeated insistence on Russia's revived superpower status, his contribution has been distinctly minor league, mainly comprising $\$ 1 \mathrm{~m}$ in food aid. It has also sent disease specialists to West Africa and promised long-term financial support for the WHO. Brazil has donated kits capable of protecting 2500 people from Ebola. India has donated \$10 m" (Tisdall, 2014). Joining the rest of the world, the affected continent itself, Africa, through its business leaders met in Addis Ababa and "raised $28.5 \mathrm{~m}$, to deploy, at least, 1000 health workers to Guinea, Sierra Leone and Liberia" (News Sections, 2014s).

\section{Territorial Democracy}

Territorial democracy or restructuring is another issue causing upheavals not only within nation states but also globally. Countries with troubled internal territorial democracy or restructuring include USA, Britain, Spain and Nigeria. The external ones are Russia and Ukraine.

1) $U S A$

Within the United States, are two examples of local and state rebellions threatening the unity of the country? First is the case of Daniel Miller whose organization has been campaigning for the State of Texas to secede from United States since the 1990s, a repeat that was made shortly after President Obama won the Presidential election for the second term (Forsyth, 2014: Online). Secondly, in the United States, "several counties have made attempts at secession. In 2013, five Colorado counties voted in a non-binding referendum to secede from the state, and part of rural Maryland announced its intents to split from metropolitan neighbors" (Forsyth, 2014: Online).

\section{2) Nigeria}

In Nigeria on the other hand, "at the local level, the prevalence of inter-and intra-community disturbances reached their peaks under Abacha's regime". Some of these communities no longer want to cohabit with one another again hence they are fighting for separate autonomy through having their own separate local governments. "Samples of them were Warri North and Warri South Local Governments crisis, Jos North and Jos South Local Government disturbances, Ife-Modakeke, Zango-kataf, and the Aguleri-Umuleri crisis among many others" (Olasupo, 2005: p. 134).

\section{3) Britain}

United Kingdom followed suit recently when one of the components of the union, Scotland, held a referendum on 19 September 2014, to break away from the union. Reasons for the breakaway from Britain, according to "the Scottish government, led by First Minister Alex Salmond, says the 300-year-old Union is no longer fit for the purpose and that an independent Scotland, aided by its oil wealth, would be one of the world's richest countries". That, it's time for Scotland to take charge of its own destiny, free from what he describes as the "shackles" of a London-based UK parliament (News Sections, 2014t). Had this been successful, the negative impact on world federalisms in particular would have been devastating. Shortly after the British rumbling, Catalonia also declared it wanted her own self-determination on 9 November.

\section{4) Spain}

When Catalonia referendum finally held on 9 November, two million out of estimated 5.4 million eligible voters took part in the ballot. $80 \%$ out of the two million voters however voted for independence. But this is against the position of the Spanish government. "Speaking beforehand, Spanish Justice Minister, Rafael Catala, dismissed the exercise as fruitless and useless". "Greed, intolerance" and "the lust for power" which Pope Francis pointed to as cause of worldwide political upheaval is again at play in Catalonia referendum. "Nationalism in Catalonia has been fuelled by economic and cultural grievances. This wealthy region of 7.5 million people con- 
tributes more to the Spanish economy than it gets back through central government funds and for this selfish reason, they want to be independent of Spain (News Sections, 2014u). Referendums in Britain and Spain were badly criticized from within and without, especially the one in Britain.

Russia started it first by crying foul over Scottish independence vote. According to Russian observers, "referendum count took place in rooms that were too big and did not meet international standards". "And that procedure was badly flawed". "In an apparent attempt to mirror persistent Western criticism of Russia's own elections, Igor Borisov-an accredited observer - said the poll failed to meet basic international norms" (Harding, 2014). In the course of the debate on Scotland's independence, President Putin made interesting intervention when asked by a reporter "whether he would be prepared to welcome an independent Scotland into the new Russian custom union? Russian President replied: 'I wouldn't rule that out'" (Macdonell, 2014). It should be noted that just as President Putin intervened to support Scotland people in their move to independence, President Barack Obama also, on behalf of the British government campaigned against Scotland's peaceful secession.

On the day of the referendum in Scotland, 18 September, President Barack Obama who had hitherto sitting on the fence, surged forward and "twitted his hopes for 'No' in today's Scottish independence referendum; saying he hopes the UK remains 'strong, robust and united". Further eulogizing Britain, Obama said, "the UK is an extraordinary partner for America and a force for good in an unstable world. I hope it remain strong, robust and united '-bo'. The signature '-bo' is used by President Obama to indicate when he is twitting directly" (Kinder, 2014). Speaking out against Scottish independence, former President Clinton also contributed that "the Scots will inspire the world with a high turnout and a powerful message both identity and inclusion" (Kinder, 2014).

\section{5) Ukraine}

Opportunity soon came for the unipolar world to launch its own blistering attack on Russia's backed elections in the pro-Russian separatists in eastern Ukraine. "The European Union has condemned as 'illegal' elections held by pro-Russian separatists in eastern Ukraine. EU foreign policy chief Federica Moghenrini said the polls were a new obstacle on the path towards peace". "The central government in Kiev also described it as a 'farce' the polls in the two self-proclaimed people's republics in Donetsk and Luthansk regions". But Russia said it "respects the will of the people" in the polls, where the two current rebel leaders are set to win". Self-proclaimed election officials say early results suggest Alexander Zakharchenko will become the regional head in Donetsk, while Igor Plotnisky will secure victory in Luhansk" (News Sections, 2014v). "This is another favourd Kremlin tactic - as seen with Russian backed splinter states such as Abkhazia and South Ossetia in Georgia and Transnistria in Moldova" (Birrell, 2014).

\section{6) Moldova}

This is another former Soviet republic with pro-Russia and pro-Western forces. Pro-Western coalition is seeking closer ties with European Union, but the Russian government is seen as piling on the pressure to sway Moldovans to change course. In the summer, Moldova - along with Ukraine and Geogia — signed an association agreement on political and economic relations with the European Union. This angered Russia, which has called on Moldova to postpone the implementation of the free trade part of the deal, as Ukraine has since agreed to do. Moscow is worried by a flood of cheap EU goods affecting its producers but some observers believe its goal is to assert what it sees as Russia's natural sphere of influence in the post-Soviet regions. Today's (30/11/2014) parliamentary election in Moldova is therefore seen as electoral contest between pro-Russian and pro-Western forces taking on an unprecedented wider significance in the shadow of the crisis in neighbouring Ukraine (News Sections, 2014w).

In anticipation pro-Western forces might have the upper hand, "Russia has banned the import of agricultural products, including wine, meat, fruit and vegetables, dealing a severe blow to Moldova's economy—one of Europe poorest, and heavily dependent on agricultural exports. It has also made a noises it would support full independence for the Russia-backed breakaway region of Trans-Dniester if Moldova cosies up too closely to the West" (News Sections, 2014w).

\section{7) Russia}

Ahead of these, earlier, "after the collapse of Soviet Union in 1991, Chechnya saw a brief period of the de facto independence, two wars with Russia and an Islamist insurgency". Finally is the current forceful annexation of Crimea by Russia from Ukraine; that has drawn global attention. On this, Russia is almost globally isolated and poised for any eventuality. The Malaysian plane with more than 80 percent Netherland passengers brought down at 33,000 feet signaled the extent to which Russia could go if it is increasingly isolated and humiliated. The west has humbled Russia ideologically territorially and now economically but not so militarily. Ideologi- 
cally, communism no longer has converts. Territorially, most of its satellites states have abandoned her for capitalism; economically, unipolar world has isolated her as President Putin is now seen ranting. "Putin accused the USA and its allies of trying to tailor the world exclusively to their needs since the end of the Cold War, using economic pressure and military force and often supporting extremist groups to achieve their goals" (Isachenkov, 2014). To all these, President Putin has served United State a notice: "If the United States fail to abandon its desire of eternal domination, then hopes for peaceful and stable development will be illusory, and today's upheaval will herald the collapse of global world order" (Isachenkov, 2014).

He therefore said "Moscow must guard against "colour revolution" seeing "what tragic consequence the wave of the so called colour revolutions has led to". Ukraine's 2004 pro-Western uprising became known as the Orange Revolution, while Georgia's Rose Revolution took place in 2008. "We have to do all that is needed to ensure that similar things never happen in Russia", Mr. Putin said. Putin's Foreign Minister, Sergei Lavrov, sums up everything by saying that "Western sanctions against Russia over its role in Ukraine are aimed at forcing regime change in Moscow" as sanctions "will destroy the economy and cause public protests" (News Sections, 2014x).

As fear began to grow among former Soviet States that Russia was about to reincarnate old Soviet Union, "Several hundred USA troops were deployed in Poland and the three Baltic States of Lithuania, Latvia and Estonia. The deployment was part of Washington's efforts to reassure the nervous eastern European allies that Nato would offer protection from any Russian threat. All three Baltic States used to be part of the Soviet Union. Much as Poland and Baltic states would wish permanent stationing of USA troops and other units on their soils, this is impossible due to concerns this would breach a 1997 Russia-Nato agreement. But "there are going to be USA army forces here in Lithuania, as well as Estonia and Latvia and Poland for as long as it is required to deter Russia aggression and to assure our allies" (The Guardian, 2014).

Warning USA on these, Henry Kissinger said "Putin is a man who wants to restore Russia to some respect. But he comes from a country that has a tradition of flexing its muscles. So, sometimes the conduct is confrontational". "Despite being bitter enemies", Kissinger went on "during the Cold War, the United States and the Soviet Union were able to develop a kind of détente - a détente that seems to be lacking even now". In the end, we and Russia can develop common objectives because where we clash are issues like Syria, where I believe we both should have the same objective, which is the radicalization of the Arab world. Because a radical Arab world will spread over into Russia before it spills over into us (Krever, 2014).

While the collapse of Cold War brought restructuring in some places, it created permanent disunity in others. In the West, it brought unification of western and eastern Germany, in the east however, it left south and North Korea permanently divided. A brief ray of hope was however flashed to the world recently when North Korea paid surprised visit to South Korea through North Korea officials for the closing ceremony of the Asian Games. "The visit was led by two top ranking North Korean officials seen as close aides to leader Kim Jong-un" (News Sections, 2014y). Less than a week however, the two exchanged fires that dampened this ray of hope (CNN, 2014h).

\section{8) Kurds}

Kurds are another group of Arabs whose predicaments may surface at the end of the current global war against ISIS. They (Kurds) are not united and don't have a country of their own despite being a nation; as they are scattered across the entire Middle East but continually dream of a state of their own. They are fighters whose fighting spirits is admired by United States of America in particular. However, "for the first time, fighters from all the big Kurdish factions in the Middle East, the whole alphabet soup of KDP, PUK, PKK and YPG, will be fighting alongside each other in the same battle - the defense of Kobane from Isil in Syria". Thus "for the Kurds-who aspire to statehood, it's a hugely powerful moment" (Spencer, 2014).

Seizing the opportunity of the crisis in Syria, Syrian Kurdish minority have set the ball rolling when for "three years" they have been "quietly building a series of mini-states in the north of the country" (CNN, 2014i). The statelets has everything it takes to be a formidable state: "Despite being mostly Sunni Muslims themselves, Kurds are decidedly secular; it "included many different ethnic groups, faith groups, and they tried to be inclusive"; their official languages included: "Kurdish, Arabic, and Syriac - an ancient Christian language spoken in the Middle East for nearly 2000 years"; in their military, women formed formidable part of infantry brigades; above all, "unlike the atmosphere in territory controlled by Islamist militias, women in the statelets walk freely on the streets, their hair and faces uncovered" (CNN, 2014i). Now that USA and allies find these Kurds useful in prosecuting ground battle against ISIS, they should not abandon them after the goal of defeating the ISIS must have been achieved. The way the unipolar world founded a state for Israel in 1948, they must find one for the 
Kurds too; for they have met the necessary western requirement for statehood: secularity, democracy and women liberation. Apart from being a big player in the global war against ISIS in Iraq and Syria. Kurds are the only nationality with huge percentage of female soldiers in any recent modern war. Figure 12 shows Kurds' women soldiers all in Western combat dressing; no purdah, no veil and no Ijab.

\section{9) China and Japan}

China and Japan almost went to war early this year over the Senkaku Islands dispute. Senkaku dispute concerns a territory dispute over a group of uninhabited islands known as Senkaku islands in Japan, Diaoyu in the People's Republic of China (PRC), and Tiaoyutai islands in the Republic of China (ROC or Taiwan). Connected to Senkaku islands is United States of America that provided a period of administration to this group of Senkaku's island between 1945 and 1972 (Wikipedia, 2014b). "The Senkakus have been a source of rising tension between the regions's two biggest economies since 2012 when Japan effectively nationalized the uninhibited islands, which are surrounded by rich fishing grounds and large untapped deposits of natural gas. This move by Japan sparked off fury in China; protesters took to the streets in several cities, forcing the temporary closure of some Japanese business in the country" (McCurry \& Branigan, 2014). The disputed group of islands among Japan, China and Taiwan is found in Figure 13.

Clearly, two nuclear power nations are involved in this China-Japan "piecemeal war": China and USA which surrogates for Japan. On a state visit to Japan early this year, President Barack Obama states categorically that "The USA is bound to come to Japan's aid in the event of a conflict with China over a group of disputed islands in the East China Sea". He further stated that "We don't take a position on final sovereignty on the Senkakus but historically they've been administered by Japan and should not be subject to change unilaterally (McCurry \& Branigan, 2014). Responding angrily to USA-Japan bilateral security treaty, Chinese foreign ministry Spokesman said that China had "undisputable sovereignty" over the islands and that "the so-called Japan-USA alliance" should be careful not to impinge on China's territorial rights (McCurry \& Branigan, 2014). Below is the picture of the location of Senkaku or what Chinese and Taiwan call Diaoyu and Tiaoyutai respectively. In Figure 14 is found the location of the disputed islands among the disputants.

In no other conflict zone is Pope Francis admonitions: "Greed, intolerance and the lust for power" as the banes of conflict all over the world more relevant than in China-Japan conflict. This is because the nations involved are not just nuclear power nations but also world economic power houses. Prior to the outbreak of Senkaku's island dispute between these two countries, there had been other conflicting issues between them. One is the "Nanjing massacre which China says 300, 000 Chinese civilians were massacred when the city was occupied by Japan's troops in 1937; though some Japanese nationalists dispute this". For the first time, China is giving this incident state commemoration which is being miss-interpreted in certain quarters. But China President Xi countered this by telling the survivors that "to deny a crime was to repeat it but insisted the ceremony was to promote peace, not to prolong it". Two, in the past, there have also been clashes between China and Japan over the latter's insistence on "honoring its war dead, including convicted war criminals, at the Yasukuni shrine" (News sections, 2014z1).

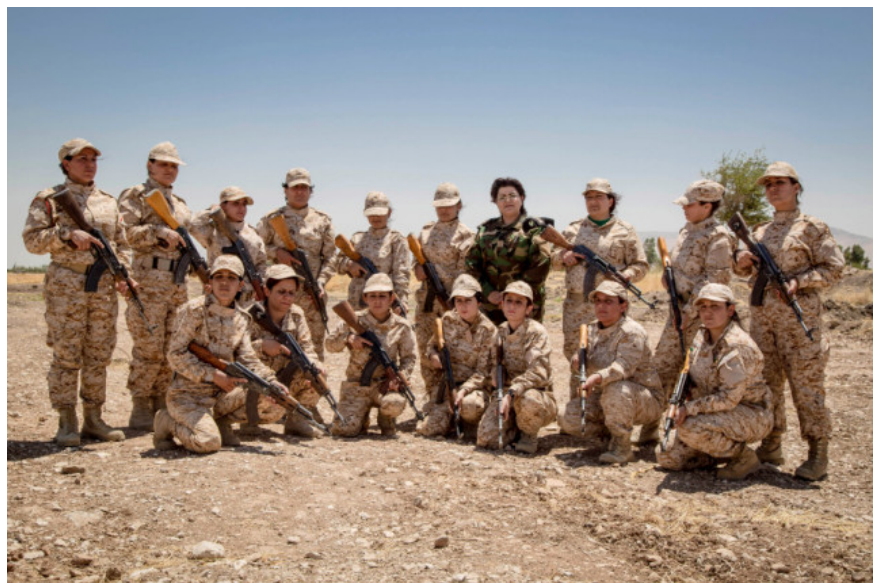

Figure 12. Female Pershmerga fighters in the ongoing Global coalition against ISIS. 


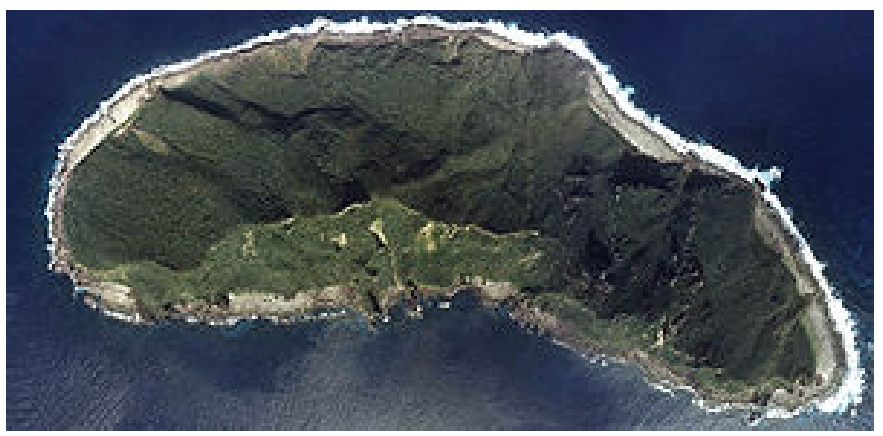

Source: Wikipedia Atom feed.

Figure 13. Uotsuri-shima, the largest of the Senkaku Islands at 4.3 $\mathrm{km}^{2}$ (1.7 sq mi), in an aerial photograph taken in 1978 by the MLIT, the omnibus ministry which operates the Japan Coast Guard.

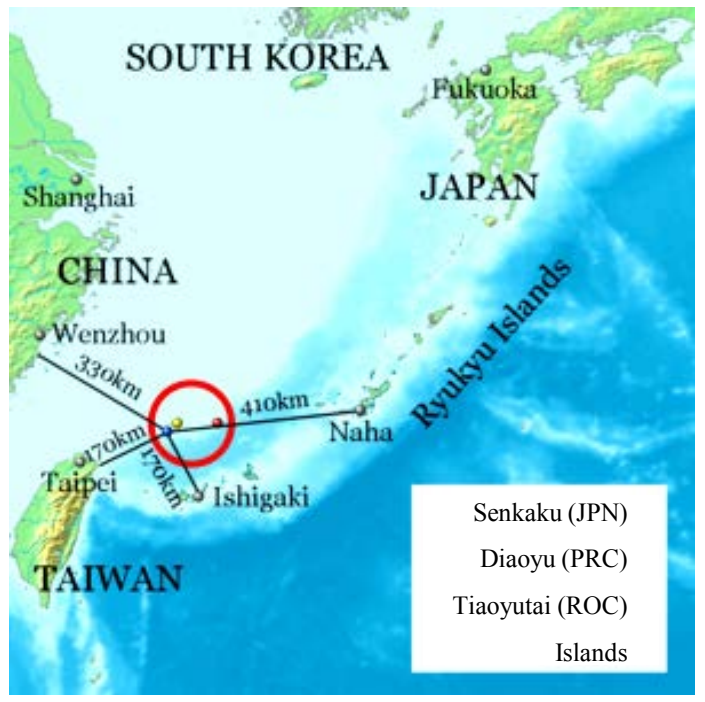

Source: Wikipedia Atom feed.

Figure 14. Location of Senkaku Islands.

\section{Nuclear Weapon}

Nuclear weapons acquisition is an issue potentially possible to cause the WW III and possibly the first thermonuclear war. The two nations at the center of these brouhahas are North Korea and Iran, and both are allies of Russia and China. While North Korea has already acquired it, Iran is in the process of doing so. The United Nation's Security Council and Major world powers are already talking to these culpable nations to drop the programmes for economic rewards but breakthrough is yet to be realized. Unlike the Second World War that saw USA being the only user of nuclear bomb to silence Japan without adequate response and reaction from any other nuclear nation; it will never be the same should any nation today use nuclear weapons to settle score (Olasupo, 2014: p. 303). So, the Third World War is going to be a war of check and balances in which any disequilibrium could result in thermonuclear war and possibly the end of the world and its civilization as we know it today.

\section{Ebola War}

This is another war deadlier than ISIS and nuclear weapon. It does not make sound but silently permeate every part of the world. It originated in Africa but cannot be confined to Africa alone. No technology will be able to do that. This is why the entire global response is required to combat it. According to Peter Piot, a microbiologist and former undersecretary general of the United Nations, also a co-discoverer of the virus, "the current Ebola 
outbreak is 'running much faster' than international response to it". "This is first Ebola epidemic where entire nations are involved, where big cities are affected" (CNN, 2014j). Because Ebola is a human-to-human transmitted epidemic, some countries have begun to shut their borders against frontline countries of Guinea, Liberia and Sierra Leone.

Some allies of USA have also joined in the isolation of these Ebola ravaged countries: Canada and Australia in particular. They are placing visa ban on the citizens of these countries intending to travel to their Western countries (News Sections, 2014z2). By these, "the three countries (Guinea, Liberia and Sierra Leone) that are affected are being totally destabilized, not only in terms of the people who are killed by Ebola - their families, the orphans that now are coming up because the parents died-but the economy has come to a standstill" (CNN, 2014k).

This has posed a serious challenge to unipolar world, particularly their headquarters, USA. Citizens of USA who have caught the virus include Ashoka Mukpo, Dr. Rick Sacra, Dr. Kent Brantly, Nancy Writebol, Dr. Craig Spencer and Patrick Sawyer who died in Nigeria (CNN, 2014l). Britain (William Pooley), Spain (Mrs Teresa Romero), and Germany (an unnamed Ugandan and a North African) have had their own share of Ebola victims. This virus without border has thus tasked the international community to find solution to it.

Spokesperson for the three Ebola ravaged country who is also American citizen abroad, the President of Liberia, Ellen Johnson Sirleaf, in a letter, presented their cases to the world leaders. The Liberian President, Sirleaf, "says the whole world has a stake in the fight against Ebola". "In a 'letter to the world' written for BBC, she said the disease "respects no borders, and that every country had to do all it could to help fight it"' (News Sections, 2014z3). Failure of which Eric Duncan's experiment would be a child's play. Liberian is the only American colony in the whole of Africa. Sizable numbers of her population are American Slaves dumped there after abolition of slavery in USA. When America therefore focused attention on her "internal citizens" to the exclusion of her "external ones", Duncan decided to elope and in the process spread Ebola war to USA. Furious at this contaminant, USA left him to die while contaminated 'internal' USA citizens are daily mounting pressure on President Barack Obama who himself is an African-American.

They had opportunity of speaking louder at the recent mid-term election held in some states across USA. "Who could have imagined Republicans winning the governorships of Maryland and Massachusetts, winning Senate seats in Obama states such as Colorado and Iowa, and assembling their biggest coalition in the House of Representatives since the 1940s" (Gergen, 2014).

It is doubtful if this situation will not create another race war between the whites and the blacks. One, the black Americans are not happy that of all American citizen, directly or indirectly, none has died in USA as a result of massive medical care for them. But the only one black "indirect citizen" who, unlike white victims who were flown abroad in specially equipped aircraft, came to USA on his own expenses was improperly catered for and had to become the first Ebola victim to die in USA. Two, the whites believe that African citizens are seizing the advantage of African-American of Kenya descent, as American head of state, to disturb their good health; forgetting that they introduced globalization, internet, Air and Water communications that integrated Africa into their systems, which they can no longer disconnect.

"With the spread of Ebola Outpacing Response, Security Council Adopts Resolution 2177 (2014) Urging Immediate Action, End to Isolation of Affected States" (UN, 2014). "Ban Ki-Moon blasts some of the world's biggest players for failing to pull their weight in fight against potentially global threat". According to him, it may not be enough. It is certainly a bit late. But at least the response to the Ebola crisis in West Africa by USA, Britain and France now involves significant commitment of people and resources. The same cannot be said of others among the world's most influential countries, whose miserly and irresponsible reaction to the epidemic belies their claims to the 21st century global leadership (Tisdall, 2014).

Expectedly, United States has picked up the gauntlet. "USA president said world leaders need to marshal extra finances and personnel to bend the curve of the epidemic in west Africa". He warned of Ebola spreading globally if more is not done to stop the epidemic raging out of control in West Africa" (World News, 2014). To that end, President Barack Obama will appoint Ron Klain his "Ebola czar". According to him, president Obama, "it may make sense for us to have one person... so that after this initial surge of activity, we can have more regular process just to make sure that we're crossing all the T's and dotting all the I's going forward" (CNN, $2014 \mathrm{~m})$. Soon after the mid-term election, he asked Congress for $\$ 6.2$ bn to fight Ebola in West Africa and to avoid it spreading in USA (News Sections, 2014z4). Following president Obama's comment is his Chairman Joint Chief of Staff, General Dempsey, "he is alarm by the World Health Organization warning that Ebola cases 
could increase and the virus could mutate. I don't want to take that chance, so, I am taking it very seriously" (CNN, 2014n).

Other responses included, "International donors" who "have given almost $\$ 400 \mathrm{~m}$ (two hundred and fifty million pounds) to UN agencies and aid organizations, short of the $\$ 988 \mathrm{~m}$ requested" (News Sections, 2014z5). World Health Organization announced that production of "millions of doses of an experimental Ebola vaccine by the end of 2015". It said "several hundred thousand would be produced in the first half of the year and could be offered to health workers on the frontline in West Africa" (Gallagher, 2014). Like ISIS crisis originating from Middle East, and Nuclear problem emanating from Asia, Ebola originated from Africa. American researchers in 1976 discovered Ebola "in what is now Democratic Republic of Congo" (CNN, 2014o).

\section{Summary}

Running through the paper, a number of observations are made. One, Pope Francis identified a number of countries where Third World War is being fought "piecemeal" today. They include "Ukraine, Iraq, Syria, Gaza, and parts of Africa". But there are other potential ones such as North and South Korea (the two Koreans remain technically at war because the 1950-1953 conflict was ended with a truce) (News Sections, 2014z5); Iran and Israel are also technically at war over acquisition of nuclear weapon. While Israel already possesses, Iran, backed by Russia and China, is still struggling to possess its own. Of recent emerged a new document by Iran's supreme leader calling for the elimination of Israel; and also calling for West Bank to be "armed like Gaza". "Armed resistance is the cure he says". The Israeli Prime minister, Netanyahu, responded that "world powers must not rush into a deal on the country's nuclear program despite an upcoming deadline", warning that "we will not let Iran acquire a nuclear weapon period", he added. "Iran must not be allowed to become a nuclear threshold power" (CNN, 2014p). Jerusalem and East Jerusalem are also at war over access by Jews to religious site in East Jerusalem. Over and above all these, the West and the East (Russia and USA) are about to resume Cold War that ended 25 years ago.

According to the former Soviet leader, Mikhail Gorbachev, "the world is on the brink of a new Cold War, and trust should be restored through dialogue with Russia". "At an event to mark the 25th anniversary of the fall of the Berlin Wall on Sunday, Mr. Gorbachev said the West had "succumbed to triumphalism" (News Sections, 2014z5). Like Pope Francis, Gorbacheve whose policy of glasnost and perestroika ended Cold War in 1989, "expressed alarm about recent Middle Eastern and European conflicts". Going further, he said "Tensions have been raised over Ukraine, which was part of the Soviet Union"; that, "Bloodshed in Europe and the Middle East against the backdrop of a breakdown in dialogue between the major powers is of enormous concern" (News Sections, 2014z5). "For this reason, the global powers had been unable to cope with conflicts in Yugoslavia, the Middle East and now Ukraine", he said. As a way forward, "former Soviet leader urged the West to lift sanctions on Russian officials - imposed over the annexation of Crimea and Moscow's alleged involvement in the Ukraine conflict - and restore trust through dialogue with the Kremlin".

The second observation is the issue of religion. The world is extremely lucky to major world powers believing in separation of religion from State affairs. Most, if not all the world powers, profess secularity in their respective countries. Imagine the West having the backing of Pope and the East that of King Fahd of Saudi Arabia, how easy would it have been to confront ISIS or ISL? If Iran had been allowed to acquire nuclear weapon like Israel what would the situation in the Middle East have been? Recall the situation during the Iraq-Kuwait war, also known as Gulf war; Iraq used scud missiles against Israel and the coalition. In the 2001 assault, Iran also fired more scud missiles at Iraq than it did during the entire Iran-Iraq war. Scud missile is a series of tactical ballistic missiles developed during the cold war and was exported widely to other countries, in particular third world countries (Wikipedia, 2014c). So, it is to the credit of world powers, particularly Russia and USA, that they have maintained highest standard of maturity on the issue of religion been part of States' matters.

That the Pope and Kind Fahd of Saudi Arabia collaborated with these world powers in the ongoing war against ISIS is also commendable. East Jerusalem and Medina are also worth mentioning here for being melting pots of both religions. While East Jerusalem contains a compound known to Jews as the Temple Mount, and to Muslims as Haram al-Sharif or the Noble Sanctuary; it is also the holiest site in Judaism, and al-Aqsa Mosque, the third holiest site in Islam is also located there. Also in Medina and, by the graveside of Prophet Mohammed, is a portion of land preserved for the second coming of Jesus Christ, so that when he finally dies, he would be buried there. Thus, in the way Kingdom of Saudi Arabia has total control of Makka as the capital of Muslim and Islamic world so does Israel wants to control the whole of Jerusalem not just as the eternal capital of Israel, but 
also religious capital of Christianity and Judaism.

Israel had previously placed age limit on Muslims women and men above the age of 35 who can enter the Al-Aqsa mosque but lifted it today 14/11/2014, "allowing Muslims of all ages to pray at the holy site" (CNN, 2014q). The fear of the younger men and teens likely to cause disturbances led Israeli authorities to take this step. To get the ban lifted however required the interventions of the Secretary to the unipolar world and the USA Secretary of State, John Kerry, Prime Minister Benjamin Netanyahu and Jordanian King Abdullah.

On Democracy, we can say there are two variants of this in the world today: open and secret democracies. While USA present the best form of open democracy, Russia, on the other hand represent the best form of secret or closed democracy. They are two contending models that, at the appropriate time, one will defeat the other in a way that capitalism defeated communism. The death of communism started where it began and it was carried out by a Russian Gorbachev rather than by any outside forces; so, USA and allies should allow communist States to peacefully detect by themselves which out of open or secret democracies is the best.

Restructuring or territorial democracy is another conflicting issue. On this, the West and the East are to blame for violent structuring and restructuring. They started it with Germany after its defeat in the Second World War. Over ambition of Germany or what Pope Francis referred to as "greed, intolerance and lust for power" led her to this. But having kept Germany divided through Berlin Wall, these two blocs, in their wisdom and compromise felt they should be reunited again, and Germany today serves as symbol of East-West unity and of course the melting pot of Europe economy. But North and South Korea divide remains. China is believed to hold the leverage towards Korean unity and she is the one the world looks up to today to set the ball of unity between the two Koreans rolling.

The recent release of three Americans, especially Bae and Miller, have thrown up some speculations as to the possible reasons for their release. One, it could be that "these people were put in jail for a certain amount of time, and now they can be released". Two, "it could be that Kim is communicating to China... that Pyongyang is trying to be reasonable, and United States is not". Thirdly and finally, "it also could have something to do with North Korea's effort to tamp down the possible fallout from a scathing UN Commission of Inquiry report cataloging North Korea's abuses that the investigators said amounted to crimes against humanity" (CNN, 2014r). Options number two and three with regards to denuclearization and human rights violations are our concern her because it is in these areas the Western powers and USA in particular regularly clash with North Korea. In any case, German Chancellor, Angela Merkel, addressed these issues in her speech during the 25 anniversary of collapse of Berlin wall. According to her, "we can change things for the better. This is the message for Ukraine, Iraq, North Korea and other places where human rights are threatened" (News Sections, 2014z6)

Women issues in Arab world in particular and Islamic world in general, particularly in the areas of dressing and women's rights in general were also discussed in the paper. Of particular interest in the paper is Arab women's dressings generally. Purdah and veil as ways of dressing are the most disgusting to the Western world. But every religion has its own Purdah. For the Christians, according to Nobel Laureate, Professor Wole Soyinka, Father Christmas is a kind of Purdah. In Africa, masquerades are also kinds of purdah. However, for the Christians, Father Christmas (Purdah) comes once in a year and it is during the Christmas day. In Africa, masquerades, (Purdah) are seasonal that last for a maximum of one week in a year. But in Arab and Islamic worlds it is a complete way of life, though it is optional; ditto for veil. However, former American Secretary of State, Hillary Clinton, Christiana Amanpour, Hala Gorani, Nobel Laureate, Malala Yousafzai and the only female pilot in the ongoing airstrike coalition against ISIS, Major Mariam Al Mansouri, have been going round the world showcasing acceptable way of Muslim women's dressing to the world. Out of the three ways of Muslim women's dressing, Purdah, Veil and Ijab, Ijab appear to be the mean and it is the one they all appear in when travelling to any part of the world especially Arab world. The choice of this Muslim way of dressing, Ijab, is in congruence with the one recommended for Christians by St Paul who said that "women should have their heads covered when they prophesy"

At the end of this airstrikes' coalition against ISIS, when ISIS would have been defeated, western powers and Arab world would need to sit down and iron out their differences in the areas of dressing code, stoning of women to death for adultery, lashing as well as other repugnant punishments like beheading. Other women's right violation such as what happened to two women in Iran recently should be addressed - the executed Reyhaneh Jabbari and the jailed British-Iranian born Ghoncheh Ghavami. This is one dimension of such conference. The second and the most important one should be that of the meeting of world powers with world religious leaders such as the Pope, King Fahd of Saudi Arabia and the religious head of the Jews. This is important for the stabil- 
ity of world peace. At the national level, this is available in most African countries like Nigeria, Senegal and Ghana (Olasupo, 2013).

On Ebola, UN, USA and European countries have risen to the occasion knowing how deadly it is. It does not need denotation or explosion; it is a quiet and fastest destroyer. Every part of the world does not need to travel to Africa, especially West Africa, to get impacted by it. It originated in Africa but discovered by a group of Americans on a research trip to Democratic Republic of Congo. President Obama has said it all, if United States does not act fast to stem and combat it in the frontline countries America and the rest of the world cannot escape it. It has claimed it first casualty in Democratic Party loosing midterm election because of poor immigration law that permitted contaminant Eric Duncan to infest Americans with it.

Nuclear proliferation, which is another big issue that could not only lead to Third World War but also First World thermonuclear War, is gradually being defeated but it surged forward yesterday, 11/11/2014. Surprisingly, Russia announced yesterday that it "plans to build new nuclear reactors in Iran". According to Russia state news agency Ria Novosti, "the country will construct up to eight new reactors for the peaceful use of atomic energy". The sudden turnabout of Russia is amazing because it is part of $5+1$ countries negotiating Iran's exist from nuclear power development (CNN, 2014s) (the $5+1$ refers to the United States, China, Russia, Britain, France and Germany-five permanent members of UN Security Council, plus Germany) (CNN, 2014p). We should recall that at the recent 25th anniversary of the fall of Berlin wall, former and the last Soviet leader and the doyen of collapse of Soviet Union as well as its communist ideology had warned that if the West did not lift the sanctions imposed on Russia, "Cold War may resume". Russia now finds a colleague in Iran. "Both Iran and Russia are under sanctions by the West. "The announcement" by Russia therefore "suggests Moscow is demonstrating that it has no plans to slow down its nuclear cooperation" (CNN, 2014s).

If Iran could be prevented from acquiring it and North Korea is subdued, to a large extent, there will be respite in the world. Otherwise, Third World War is not just going to be conventional war that we know and used to; it certainly going to mutate to thermonuclear Armageddon. When America used it against Japan, it had no rival then, but now that Russia and China also have it in abundant just like many Western European countries, an outbreak of nuclear war would be the end of the world and its centuries' built-up civilization as we know it today.

However, the recent G20 meeting in Brisbane, Australia, presented a good opportunity for world leaders to iron out their differences. Rather, Russia became focus of criticism from western powers particularly from Canadian Prime Minister, Stephen Harper who told Russian President Vladimir Putin that he needed to "get out of Ukraine"; for USA President Barack Obama, Moscow "aggression" in Ukraine was a "threat to the world" while UK threatened more Sanctions unless Russia stopped "destabilizing" its neighbor (News Sections, 2014z6). For Abbott, the host of the conference, "one of the points I tried to make to Putin is that Russia would be so much more attractive if it was aspiring to be a superpower for peace and freedom and prosperity; if it were trying to be a superpower for ideas and values instead of trying to recreate the lost glories of tsarism or the old Soviet Union and he accused Russia of stepping up its aggression, which was part of a "regrettable pattern" (Doherty, 2014; CNN, 2014t). To these fierce criticisms President Putin faced from Western leaders over Ukraine conflicts, Putin responded when interviewed by pressmen that "the summit was constructive and useful" (News Sections, 2014z6).

Now, President Vladimir Putin is increasingly under isolation - subjected to snubs, shunned at lunch and berated by other world leaders (Birrell, 2014). This is more "evident with his placing on the outer edge for the formal G20 leaders group photograph (see group photograph of G20). While Obama and Chinese Premier Xi Jinping were met by Australia's governor general and attorney general when they arrived in Brisbane and similar warm reception was given to German Chancellor Angela Merkel and Chinese President Xi Jinping; Putin was greeted by the assistant defense minister (News Sections, 2014z7; CNN, 2014t). As Birrell interestingly puts it, "Putin was being sent to diplomatic Siberia".

These imply one that the West has succeeded in driving a wedge between Russia and China. Two, While China has been recognized as economic superpower at par with USA, Russia is gradually being made a pauper with the crippling economic sanctions imposed on it by the West. As global economic superpowers, "these two largest economies", USA and China, "energy consumers and emitters of greenhouse gases" they "have a special responsibility to lead the global efforts against climate change", President Obama said at joint news conference with Xi in Beijing (Hoye \& Yan, 2014). But while China is now economic superpower, Russia remains military superpower able to stand up to USA and her allies. However, it must be acknowledged that despite the economic setback of Russia, it has played heroic role in preventing unipolar world from becoming world tyrant. Figure 15 shows how President Putin is degraded by being placed on the outer edge for the formal G20 leaders photograph. 


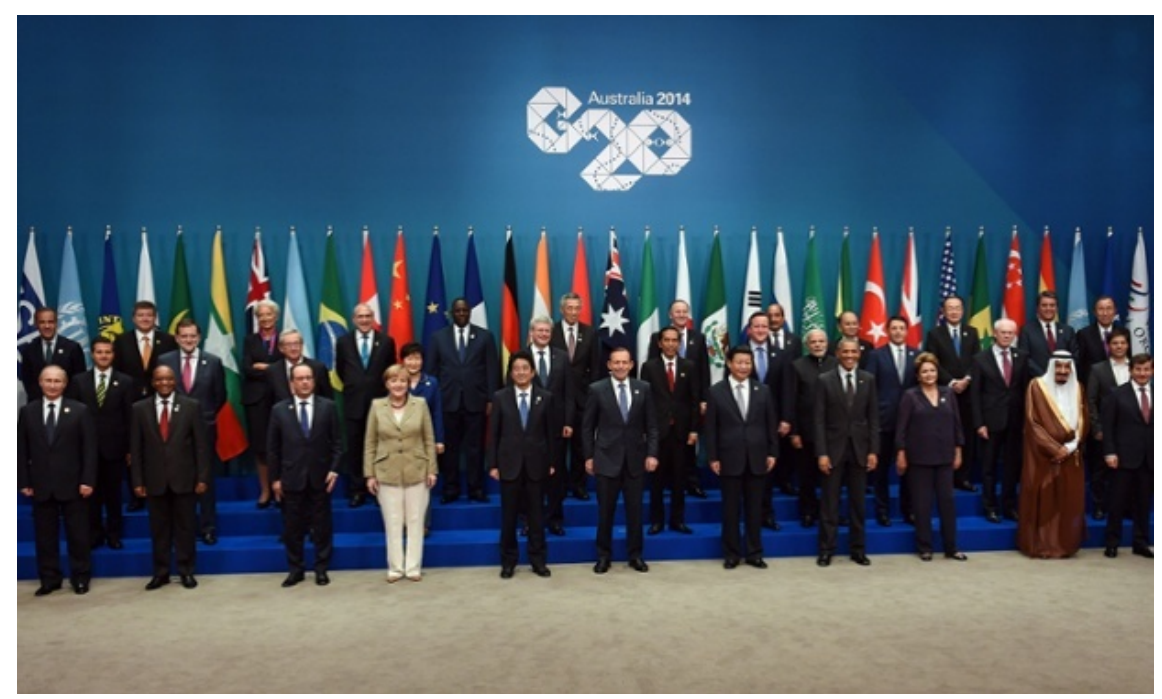

Figure 15. On the left of the group photograph is President Putin derogatorily placed on the outer edge for the formal G20 leaders photograph.

\section{Conclusions}

Delivering his judgment on most of the issues raised in this paper, the Pope seized the opportunity of his visit to European Parliament in Strasbourg to castigate unipolar world on religion, technology, economy and immigrants. As earlier suggested somewhere in this paper, on religion, especially inter religious conflict, Pope Francis told reporters on his way back home from Strasbourg to Rome "that the door should not be shut to dialogue with the Islamic State group" (Menu, 2014).

Broadly speaking, "the Pope called for 'a dialogue which can deepen the understanding and appreciation' between faith" (News Sections, 2014z8). The Pope had chosen Turkey, which "bridges principally Christian Europe and mainly Muslim Middle East" and also "is a meeting point of religions and cultures", to spread his message of inter-faith dialogue. While addressing President Erdogan of Turkey, the Pope denounced the persecution of Christians, saying that "it is essential that all citizens-Muslim, Jewish and Christian-both in the provision and practice of the law enjoy the same rights and respects the same duties". He added that "fanaticism and fundamentalism, as well as irrational fears which foster misunderstanding and discrimination, need to be countered by the solidarity of all believers" (News Sections, 2014z9). In a nut shell, Pope Francis is urging respect and cooperation by each side for the other.

Responding, President Erdogan of Turkey said that "the West must do more to combat islamophobia". According to President Erdogan, "racism and islamophobia in the West and violence and terrorism in Islamic lands make it important that we come together and cooperate". He also condemned what he termed the international "silence" over "state terror" being instigated by the Syrian government. Turkey is a country of 80 million citizens who are 99\% Muslims with just about 120,000 Christians - once the center of the Orthodox Christian world during Byzantine Empire.

At Hagia Sofia, a spectacular and interesting drama on how religion should be a symbol of unity rather than divide and rule was staged by the Pope and the city's top Muslim cleric inside the Blue Mosque. The Blue Mosque itself is a drama in dynamics. Hagia Sofia was for almost 1000 years "the most important Orthodox cathedral, then for nearly five centuries a mosque under Ottomans, and is currently a museum". It was inside this "Blue Mosque, one of the greatest masterpiece of Ottoman architecture, the Pope turned east towards Mecca, clasped his hands and paused for two minutes as the Grand Mufti of Istanbul, Rahmi Yaran, performed a Muslim prayer" (News Sections, 2014z10). Jerusalem, especially east Jerusalem, Istanbul, formerly Constantinople, was the capital of Byzantine Empire, "a place where religions, empires and cultures collided". On Empires, there are basically two: the largely-Christian Byzantine and the largely-Muslim Ottoman Empire that supplanted Byzantine in 1453. Currently, there are three basic religions: Islam ( 80 million people, religiously headed by Rahmi Yaran); Christians (120,000 headed by Bartholomew); Jews (17,000 headed by Chief Rabbi of Turkey, Isak Haleva). So culturally, Turkey is made up of Arabs, Christians and the Jews. 
Surprisingly, the kind of outreach that Popes make to different parts of the world regardless of religion is not found with King Fahd of Saudi Arabia. Rarely does King Fahd pay visit to Muslim countries not to talk of none Muslim countries. Since Pope Francis came to office, he has visited a number of Islamic and Christian countries. He has also visited the melting pot of religions Jerusalem. Despite Jerusalem's harboring of the third holiest site in Islam Haram al-Sharif and the al-Aqsa Mosque, it is not on record that King Fahd has ever visited this Islamic religious site. As a matter of fact, the Pope and King Fahd should be encouraged to exchange visits and occasionally hold meetings at Temple Mount and Haram al-Sharif alternately.

For technology and economic questions, this is the verdict of Pope Francis: "Technology and economic questions are dominating political debate, to the detriment of concern for human beings". Technology here mainly refers to nuclear technology. On migrants, he said "there needs to be a united response to the question of migration". "The boats landing daily on the shores of Europe are filled with men and women who need acceptance and assistance" and not to allow the Mediterranean to become a "vast cemetery" (Menu, 2014).

In sum, Pope Francis "declared that the EU had lost its bearings". That, Europe had become "elderly and haggard", hostage to a uniform economic model that undermined democracy while the centrality of human rights was becoming confused and supplanted by individualistic narcissism. Finally, he added "the rest of the world viewed Europe with "aloofness, mistrust and suspicion" (The Guardian, 2014). Could these criticisms of Pope Francis be a damning of the West (unipolar world) and upholding of what Russia stands for?

Whatever the case, America and Russia, represented by Presidents Obama and Putin respectively, today are the current trouble shooters in the world. They split Germany into East and West Germany before reuniting them; they divided Korea into South and North Korea. These then mean that as they are capable of triggering the Third World War and the First Thermonuclear War, they also hold the keys to World peace. This is what Pope Francis has seen and therefore admonishes "humanity to weep", and according to him, "this is the time to weep" (Rellanini, 2014).

\section{References}

Ateku, B. (2014). White House Intruder Dominic Adesanya Shows Security Lapses Still Exist. 24 October 2014.

BBC (2014). \#BBC Trending: Saudi Woman Driving Blog “Arrest”. 3 December 2014.

Birrell, I. (2014). The West Is Letting Putin Get His Way on Ukraine. The Guardian, 27 November 2014.

Brunnstrom, D., \& Wroughton, L. (2014). China Facing Growing U.S. Pressure over Hong Kong Protest. 30 September 2014.

CNN (2014a). Canadian Shooting: What We Know. 23 October 2014.

CNN (2014b). 3 Girls Sneaked Off and Tried to Join ISIS. 22 October 2014.

CNN (2014c). Who Is Part of the Coalition to Battle ISIS? 7 October 2014.

CNN (2014d). Iran's President Calls Airstrikes on ISIS “Theater”, Says Broader Campaign Needed. 26 September 2014.

CNN (2014f). 50 Arrested in Slaying of Christian Pakistani Couple. 6 November 2014.

CNN (2014g). Thousands at Hong Kong Protest as Occupy Central Is Launched. 27 September 2014.

CNN (2014h). USA Used Nazis as Cold War Spies. 28 October 2014.

CNN (2014i). North and South Korea Exchange Fire. 10 October 2014.

CNN (2014j). Meet America's Newest Allies: Syria’s Kurdish Minority. 29 October 2014.

CNN (2014k). Microbiologists: Ebola Is Faster than USA. 17 October 2014.

CNN (20141). Who Are the American Ebola Patients? 6 October 2014.

CNN (2014m). Obama Will Name Ron Klain Ebola Czar. 18 October 2014.

CNN (2014n). Gen. Dempsey: “I Don't See” Baghdad Falling.

CNN (2014o). Microbiologists: Ebola Is Faster than USA. 17 October 2014.

CNN (2014p). Iran Leader Calls for Annihilation of Israel. 10 November 2014.

CNN (2014q). Israel Lifts Age Restrictions at Holy Site. 14 November 2014.

CNN (2014r). Why Now? North Korea's Release of Bae, Miller Raises Questions.

CNN (2014s). Russia Steps up Nuclear Plans in Iran. 11 November 2014.

CNN (2014t). World Leaders Take Putin to Task at G20. 16 November 2014. 
CNN, Amanpour (2014e). Henrry Kissinger Tells Christiana Amanpour: "I Support President Obama” on Syria.

Cofflard, M. (2014). UK Grapples with the Delicate Issue of Returning Jihadists. 21 October 2014.

Dalrymple, W. (2014). Mecca: The Sacred City Review-An Important Study of One of the Great Religious Sites. The Guardian, 26 October 2014.

Doherty, B. (2014). G20: Canadian Prime Minister Shirtfronts Vladimir Putin Instead. The Guardian, 15 November 2014.

Effiong, I. (2014). Chibok Girls and the Significance of Malala's Visit to Nigeria. The Sahara Reporters, 14 July 2014.

Ehret-Kump, M., \& Spannaus, N. (2014). Prince Charles Speaks for the Evil Empire. The Executive Intelligence Review, 30 May 2014.

Feeds, The Dish (2014). Our Arab Coalition against ISIS.

Forsyth, F. (2014). TOP NEWS: Scottish Independence Vote Cheers Supporters of Texas Secession. Reuters, 16 September 2014.

Gallagher, J. (2014). Millions of Ebola Vaccine Doses by End of 2015. 24 October 2014.

Gergen, D. (2014). The Sobering Message for Obama. CNN.

Harding, L. (2014). Russia Cries Foul over Scottish Independence Vote. The Guardian, 19 September 2014.

Home Menu. (2014). Pope Francis Criticizes "Elderly” Europe.

Hoye, M., \& Yan, H. (2014) USA and China Reach Historic Climate Change Deal, Vow to Cut Emissions. CNN Edition International, 12 November 2014.

Isachenkov, V. (2014). Putin Accuses USA of Undermining Global Stability. 24 October 2014.

Johnston, C., \& Willsher, K. (2014). French Tourist Beheaded in Algeria by Jihadis Linked to Islamic State. The Guardian, 25 September 2014.

Jones, A., Almasy, S., \& Sanchez, R. (2014). Protest Feature Demands, Die-Ins. CNN, 6 December 2014.

Khoury, J. (2014). Israeli Citizens Fighting for Islamic State: A Small, yet Worrying Trend. Israel News, 18 October 2014.

Kim, S. (2014). Meet the Female Pilot Who Led Airstrike on ISIS. ABC News, 25 September 2014.

Kinder, T. (2014). Scotland Independence Referendum: President Obama Tweets Support for "No" Vote. 18 September 2014.

Krever, M. (2014). Henry Kissinger Tells Christiana Amanpour: "I Support President Obama on Syria".

Macdonell, H. (2014). Putin's Strange Intervention over Scottish Independence. Feeds, 20 January 2014.

McCurry, J., \& Branigan, T. (2014). Obama Says USA Will Defend Japan in Island Dispute with China. The Guardian

McDermott (2015). Muslim Drag Act “Gets Death Threats” for His London Act. 6 January 2015.

News Sections (2014a). Yemen Kills “Al-Qaeda Militants Disguised as Veiled Women”. 13 December 2014.

News Sections (2014b). Coptic Christian Landmark Church Restored in Cairo. 11 October 2014.

News Sections (2014c). Sweden to Recognize Palestinian State. 3 October 2014.

News Sections (2014d). MPs Back Palestinian Statehood alongside Israel. 13 October 2014.

News Sections (2014e). Rebuilding Gaza: USA Pledges \$212 m at Donor Meeting. 12 October 2014.

News Sections (2014f). Rebuilding Gaza: Donors Pledge \$5.4 bn at Cairo Summit. 12 October 2014.

News Sections (2014g). Palestinian Driver Has Rammed into Several Pedestrians in Jerusalem, Killing a Policeman, Hours after the Clashes at the City's Holiest Site. 6 November 2014.

News Sections (2014h). Synagogue Attack: Netanyahu Vow in "Battle for Jerusalem”. 18 November 2014.

News Sections (2014i). Al-Shabab Massacres Non-Muslims at Kenya Quarry. 2 December 2014.

News Sections (2014j). Kenya Bus Attack: Al-Shabab "Wants Religious War”. 22 November 2014.

News Sections (2014k). Christians Hold Christmas Eve Mass in Bethlehem. 25 December 2014.

News Sections (20141). The Jews of Arabia. Magazine Monitor. 13 December 2014.

News Sections (2014m). Pope Declines Dalai Lama Meeting in Rome. 12 December 2014.

News Sections (2014n). Thousands at Hong Kong protest as Occupy Central Is Launched. 27 September 2014.

News Sections (2014o). Xi Jinping Defends “One China” Principle during Macau Visit. 20 December 2014.

News Sections (2014p). Iran Hangs Reyhaneh Jabbari despite Campaign. 25 October 2014.

News Sections (2014q). Volley Ball Woman Ghoncheh Ghavami Out of Iran prison. 23 November 2014.

News Sections (2014r). Eric Garner Death: UN Fears over No-Charge Jury Decisions. 5 December 2014. 
News Sections (2014s). Ebola Outbreak: Africa Sets up \$28.5 m Crisis Fund. 8 November 2014.

News Sections (2014t). Scottish Independence: What's Going on in Scotland? 9 September 2014.

News Sections (2014u). Catalonia Vote: 80\% Back Independence-Officials. 10 November 2014.

News Sections (2014v). Iran Sentences British-Iranian Activist Ghoncheh Ghavami over Volleyball Game. 2 November 2014.

News Sections (2014w). Moldova Election: Will Voters Choose EU or Putin? 29 November 2014.

News Sections (2014x). Ukraine Crisis: Lavrov Warns over Russia "Regime Change" Goal. 22 November 2014.

News Sections (2014y). Ukraine Crisis: Rebel Elections Obstacle to Peace-EU. 3 November 2014.

News Sections (2014z1). Ebola Crisis: Canada Visa Ban Hits West African States. 1 November 2014.

News Sections (2014z2). Liberia's Ellen Johnson Sirleaf Urges World Help on Ebola. 19 October 2014.

News Sections (2014z3). Ebola Outbreak: Barack Obama to Ask Congress for \$6 bn. 5 November 2014.

News Sections (2014z4). North and South Korea Agree to Talks. 4 October 2014.

News Sections (2014z5). Ex-USSR Leader Gorbachev: World on Brink of New Cold War. 8 November 2014.

News Sections (2014z6). Berlin Wall: Angela Merkel Hails Fall as "Dream Come True". 9 November 2014.

News Sections (2014z7). Ukraine Crisis: Russia under Pressure at G20 summit. 15 November 2014.

News Sections (2014z8). G20: Abbott Outlines Economic Pledges. 16 November 2014.

News Sections (2014z9). Pope Francis in Turkey Urges Help for Syria Refugees. 28 November 2014.

News Sections (2014z10). Pope in "Silent Adoration" in Istanbul Blue Mosque. 29 November 2014.

News, M. (2014) USA Expands Global "War on Terror by Striking ISIS Targets In Syria”. 23 September 2014.

Olasupo, F. A. (2005). National Question and Politics at the Local Level. In W. Alli, (Ed.), Political Reform Conference, Federalism \& the National Question (pp. 134). Abuja: Nigerian Political Science Association (NPSA).

Olasupo, F. A. (2011). Origin of Civil Conflicts in the West African Sub-Region: The Micro Examples of Nigerian Universities. Gandhi Marg, 33, 115. www.gpfindia.org

Olasupo, F. A. (2013). The Role of Arabian and Western Civilization in the Extinction of African Traditional Religion: The Case Studies of Senegal, South Africa and Nigeria. International Journal of Sustainable Development, 5, 29.

Olasupo, F. A. (2014). Unipolar World in Crisis as Russia Challenges USA and Allies, Dragging Other Disgruntled Countries Along. Advanced in Applied Sociology, 4, 85-107.

Rellandini, S. (2014). Pope Says World Many Conflicts Amount to Piecemeal World War Three. Reuters, 13 September 2014.

Snedden, M. (2014). When Christmas Is a Way of Life. BBC Navigation Menu, 25 December 2014.

Spencer, R. (2014). Who Are the Kurds? A User's Guide to Kurdish Politics. The Telegraph, 30 October 2014.

Steele, J. (2011). Mikhail Gorbachev: I Should Have Abandoned Communist Party Earlier. The Guardian, 16 August 2014.

The Commentary (2014). North Korean Leader Killed His Uncle by Feeding Him Alive to Pack of Hungry Dogs-Report.

The Guardian (2014). Pope Francis Attacks EU over Treatment of Immigrants. The Guardian, World, Europe.

The Guardian (2014). USA to Keep Troops in Poland and Baltic States for at Least Another Year. The Guardian, World.

This Day (2014). Boko Haram in New Video Claims Beheading Missing Nigerian Pilot. 3 October 2014.

Timpson, T. (2014). What Did St Paul Say about Women? BBC News Sections.

Tisdall, S. (2014). UN Gets Tough on Ebola Shirkers. 17 October 2014.

Wikipedia (2014a) Murder of Lee Rigby. Wikipedia Atom Feed, Last Modified on 27 September 2014.

Wikipedia (2014b). Senkaku Islands Dispute. Wikipedia Atom Feed, 30 October 2014.

Wikipedia (2014c). The Free Encyclopedia.

World News (2014). Obama Declares USA Must Be More Aggressive in Monitoring Ebola. The Guardian, 15 October 2014. 
Scientific Research Publishing (SCIRP) is one of the largest Open Access journal publishers. It is currently publishing more than 200 open access, online, peer-reviewed journals covering a wide range of academic disciplines. SCIRP serves the worldwide academic communities and contributes to the progress and application of science with its publication.

Other selected journals from SCIRP are listed as below. Submit your manuscript to us via either submit@scirp.org or Online Submission Portal.
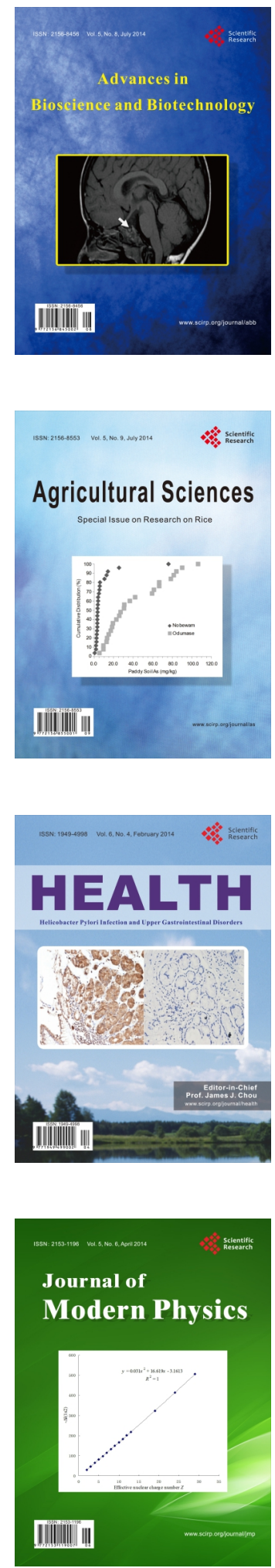
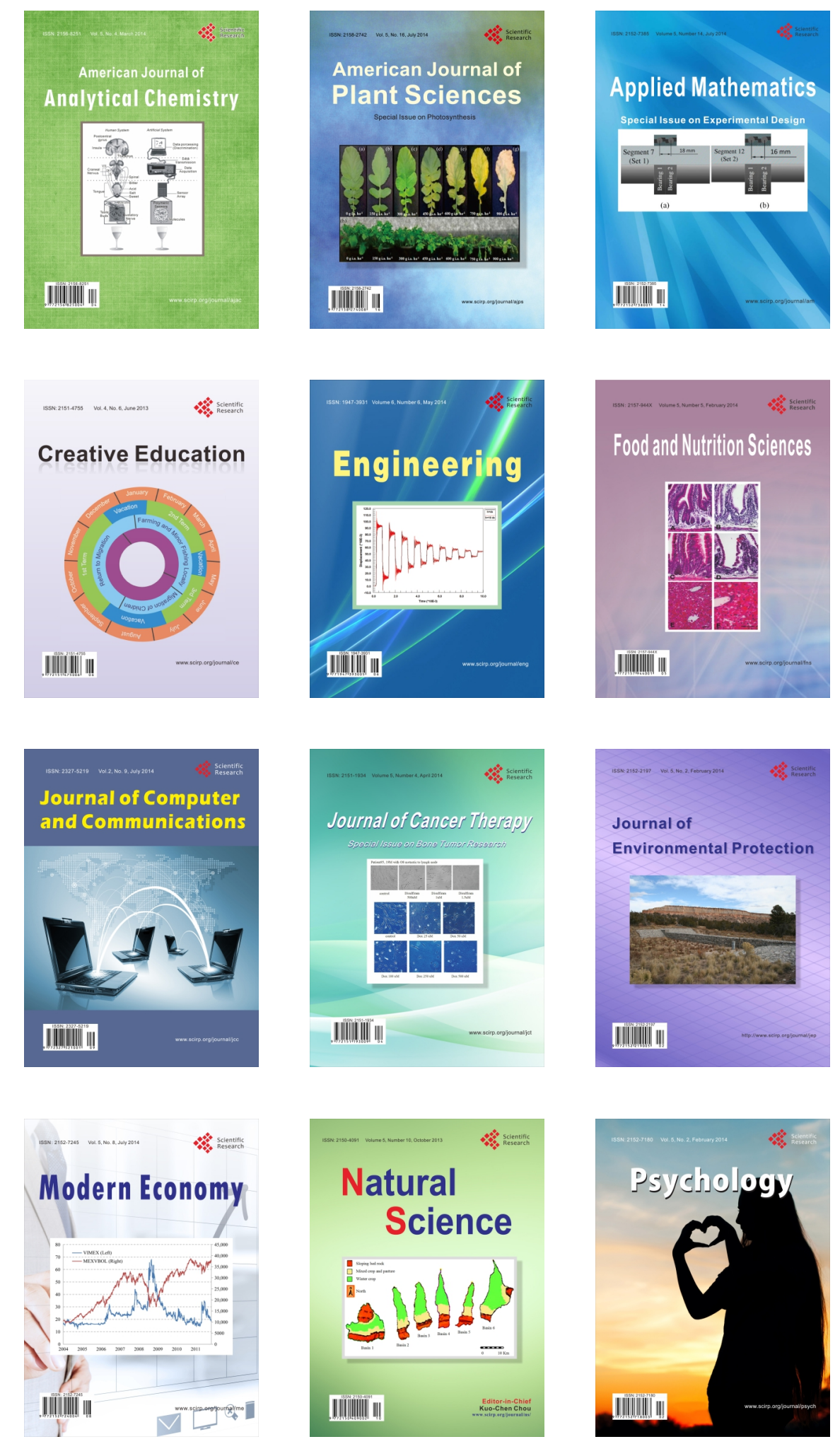